\title{
دور المرشدة الطلابية في حل مشكلة انخفاض الدافعية للتعلم من وجهة نظر الطالبات
} "دراسة ميدانية على عينة من طالبات المرحلة الثانوية بمدينة جدة"

The School Factors beyond the Degraded Learning Motivation and the Role of the Students Guide in Solving them: The Perspective of Jeddah Secondary Schools Students

$$
\begin{aligned}
& \text { الباحثة } \\
& \text { وئام بنت حامد الرايقي } \\
& \text { جامعة الملك عبد العزيز } \\
& \text { جدة - الملكة العربية السعودية }
\end{aligned}
$$


الطالبُّرَجالتعليمو الهدفالأسمدنالعمليةالتربوينقو التعليميةو عليهتعقدالآمالفيالبناءو الرقيللمجتمعالذيبعيشفيهونوج

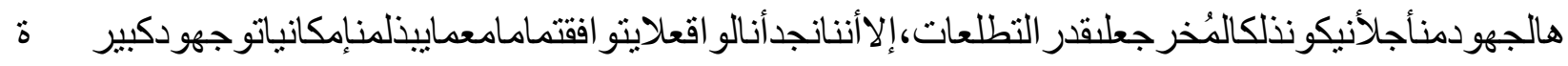
انخفاض الدافعية

،ينأنمشكلة

للتعلم أصبحتمشكلةًارزةًَعانيمنهاالميدانالتربوي،و انعكسأثر هافيضعفالمخرجفيالتعليمالعا لي(المنجومي، 2011م:

فقد أثنارت الفة التنمية التاسعة بالمملكة العربية السعوديةأن قطاع التعليم ماز ال يو اجه العديد من التحديات و المعوقات منها:ضعف الاتساق بين مدخلات النظام ومخرجاته،ففي حين تصل نسبة الإنفاق على

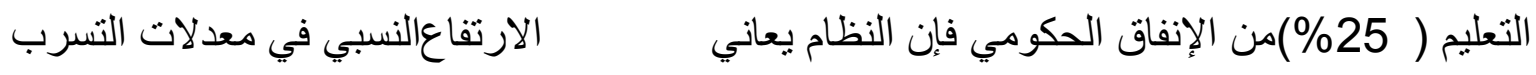
و الرسوب،بالإضافة إلى الضعف النسبي في مستوى الخريجات بصورة تجعله غير منوائم مع سوق العمل(الإدارة العامة للتخطيط و السياسات،وكالة الوزارة للتخطيط 2010م-2014م: 33).


المعرفة،قفد ذكر (مسلم،2002م) في در استه أن أحد أهم المشكلاتلتيتحدمنفعاليةالعمليةالتعليمية هي انخفاض الدافعية للتعلم بنسبة( 77.1\%)،كما أثبتت در اسة(الزبيدي،العكايشي،2006) أن أهم الأسباب النفسية لتدني التحصبل الدر اسي هو انخفاض الدافعية للتعلم بنسبة مقدار ها(97.9\%). ور غم اهتمام المملكة العربية السعودية بيدان التعليم على كافة مر احله العامة و العالية و تسخير ها الإمكانات اللازمة،ووضع الخطط التطويرية من أجل الرقي بعناصر العملية التربوية كلها،إلا أنه لايخلو نظلم تعليمي من معوقات تقف عائقاً أمام هذا التقدم.والنظام التعليمي يتألف من عناصر متر ابطة،الخلل في عنصر يؤثر على بقية العناصر .كما شُكل البيئة المدرسية منظومة متكاملة ومنسجمة،إذا اختل فيها عنصر انهد مت جميع الأركان،بدءاً من المبنى الذي يجب أن يشكل فضاء مريحاً للطالبة،يوفر كل مستلزمات الأنشطة التربوية ،ويتيح لها مجالاً فسيحاً للاندماج في الوسط التربوي(المنجومي،2011م:49). كما تنبه الباحثون إلى أن مشكلة انخفاض الدافعية للتعلم مشكلة تستحق التدخل و العلاج لمالها من تبعات سلبية على المستوى الفردي والمجتمعي، ومن الآثار السلبية الناتجة عن انخفاض الدافعية للتعلم والتي

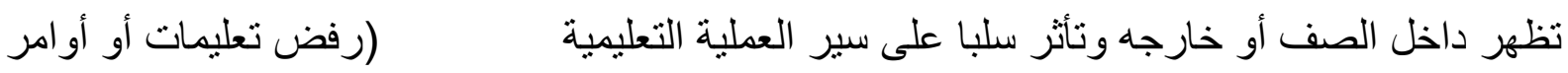
المعلم،التسرب الفكري ( السرحان) من جو الحصة،إهمال الواجبات الدراسية،التأخر الصباحي عن المدرسة أو التأخر عن حضور الطابور الصباحي،الإخفاق في الاختبار ات المدرسية ،إثارة الفوضى و العبث بالمر افق

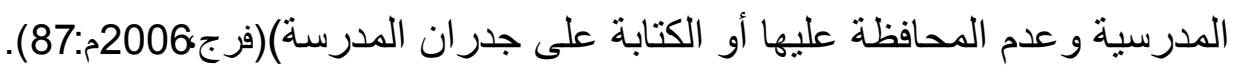
و هناك العديد من العو امل التي تسهم في خفض مستوى دافعي ة الطلاب للتعلم لكالخلافات الأسرية التي تشعر الطالب بعدم الأمان بالإضافة النبذ والحرمان والقسوة التي تؤدي بالطالب إلى انخفاض الدافعية 
للتعلم،و المشكلات الصحية مثل الخلل في الجهاز العصبي أو غيره الذي يترتب عليه صعوبة في



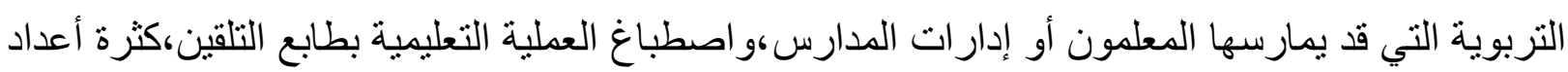
الطلاب في الفصول)(خليفة، 2001م:7). و تعدالمرحلةالثانوية

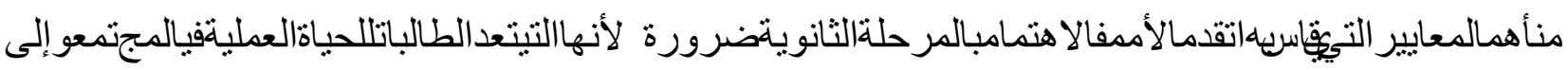

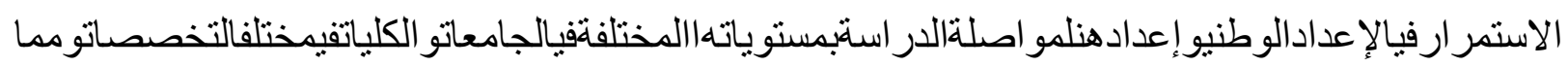

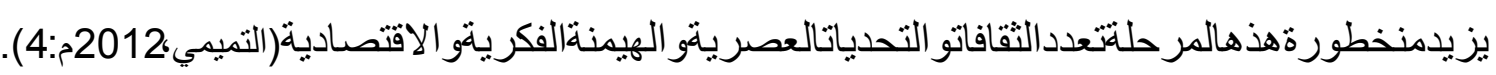

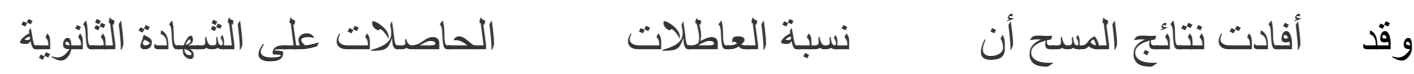
بنسبة 17.4\%.(مصلحة الإحصاءات العامة و المعلومات، 2012)ممايشير إلى عدم رغبة الطالبة في مو اصلة التعليم أو عدم قدرتها على الإلتحاق بالجامعة لتندي مستو اها التحصيلي وفي كلا الحالتين هنالك إنشارة لانخفاض دافعيتهن للتعلم. و العرشدة الطلابية في الدرسة هي صمام الأمان ولها بالغ الأثر في حل مشكلات الطالبات ومساعدتهن

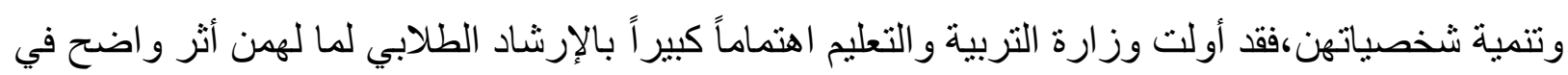

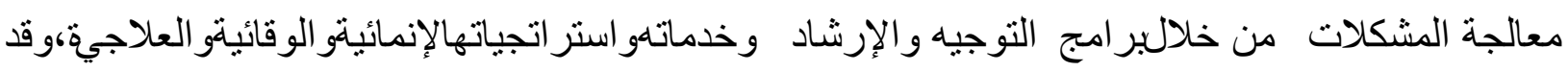
اهتمت الدراسة الحالية بمعرفة دور ها في مواجهة مشكلة انخفاض الدافعية للتعل

\section{مصطلحات الار اسة:}

1) الدافعية للتعلم:

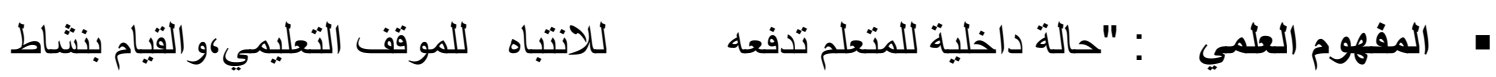
موجه،و الاستمر ار في النشاط حتى يتحقق الهدف من التعلم"(قطامي،1992م:17).

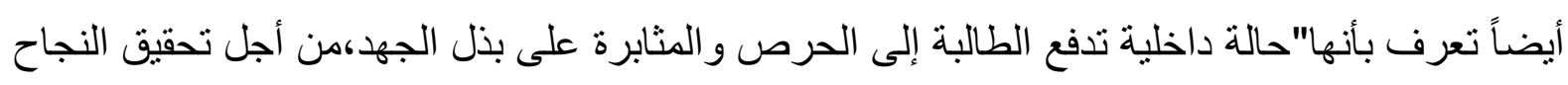

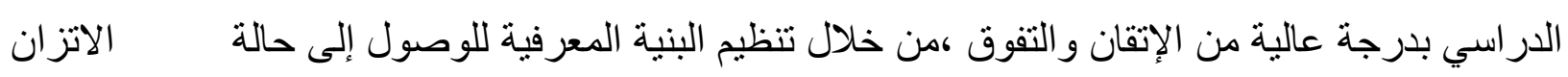

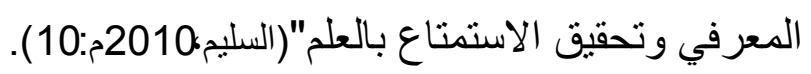

• المفهوم الإجرائي:ر غبة الطالبة في النجاح وبذل الجهد لتحقيق التميز في التحصيل الدراسي ويشمل

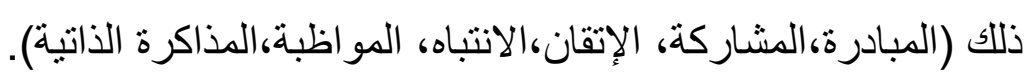

3)|نخفاض الدافعية للتعلم:

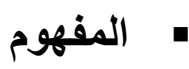

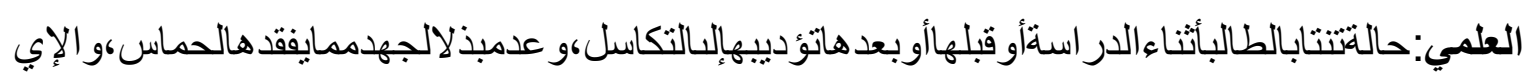


جابيةاللازمةلكأداء المدرسي و عدم المشاركة في الأنشطة الصفية



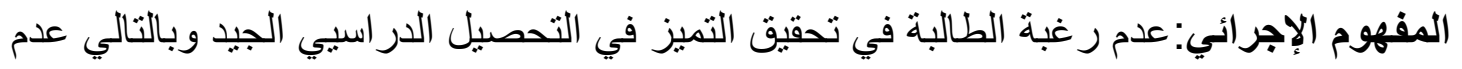
مبادر اتها للتعلم الذاتي و الإنجاز و التفوق الدراسي وذللك لأسباب تتعلق بالأبعاد التالية(المعلمة، الييئة الصفية).

ه

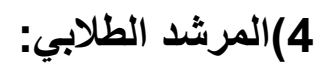

الذيبقو مبمساعدةالطالبلكييفهذذاتهو يعر فقدر اتهو ينميإمكاناته،ويحلمشاكلهليصلإلالنحقيقتو افقهالنفسيو الاجتما

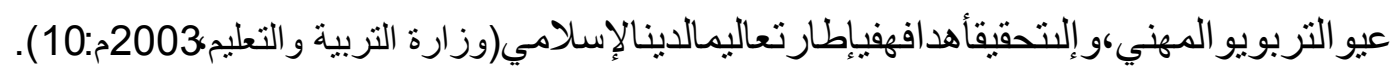

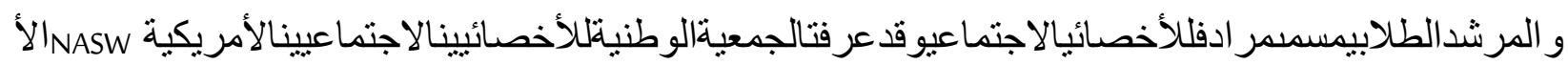
خصائيالاجتماعيبأنه ممارسيتطلبإعدادهتعليماً خبر هتمكنانهمنتو فيرخدماتو قائيةو علاجيةمباشرة ثلأفر ادو الأسرو الجماعاتالذينيعانونمن تأثثير الضغوطالاجتماعيةو النفسيةوسو عالصحة" (مو قعالفريقالاجتماعي 2013م). هالمفهوم الإجرائي:تقصد الباحثة بالمرشدة الطلابية هي المعينة من قبل وزارة التربية والتعليم بمدارس

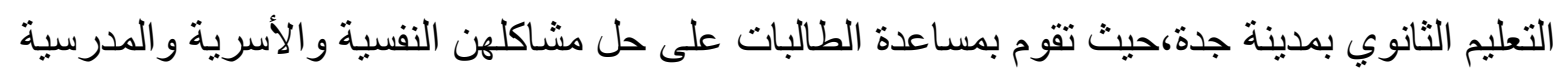

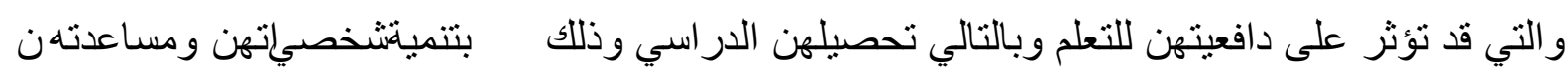
علتجاوزمشكلاتهنمنطلقةمنمبادئالدينالحنيف.

$$
\text { يتمثل الهدف الرئيسي للار اسة في: }
$$

التعرف على دور المرشدة الطلابية في حل مشكلة انخفاض الدافعية للتعلم من وجهة نظر طالبات المرحلة الثانوية. ويتفرع منه الأهداف الفرعية:

1. الكثف عن توجهات الطالبات حول دور المرشدة الطلابية في حل مشكلة انخفاض الدافعية للتعلم. r. التعرف علالفروق بين منوسطات استجابات طالبات المرحلة الثانوية حولدور المرشدة الطلابية في حل

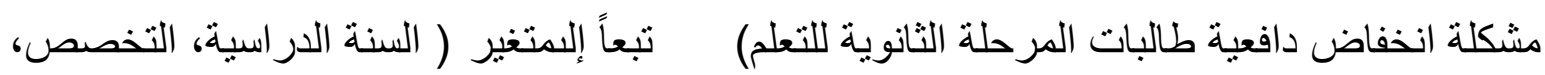
المستوى التعليمي للأب، المستوى التعليمي للأم).

$$
\text { تساؤلات الاراسة: }
$$

تسعى هذه الدراسة إلى الإجابة على التساؤل الرئيسي التالي: مادور المرشدة الطلابية في حل مشكلة انخفاض الدافعية للتعلم من وجهة نظر طالبات المبلى المرحلة الثانوية؟ 
ويتفرع من التساؤل الرئيس الأسئلة الفرعية التالية:

ا. . ماهي توجهات الطالبات حول دور المرشدة الطلابية في حل مشكلة انخفاض الدافعية للتعلم ؟ r. هل توجد فروق ذات دلالة إحصائية بين متوسطات استجابات طالبات المرحلة الثانوية حولدور المرشدة الطلابية في حل مشكلة انخفاض دافعية طالبات المرحلة الثانوية للتعلم) تعزى إلى ( السنة الدراسية، التخصص، المستوى التعليمي للأب، المستوى التعليمي للأم) ؟ الار اسات السابقة

أولاً:الار اسات المحلية:

دراسة"العويس"( 2011م)بعنوان(اتجاهات طلاب المرحلة الثانوية نحو المرشد الطلابي بمدينة بريده) تمثلالهدفالرئيسلهذهالدر اسةفيالتعر فعلناتجاهاتالطلابفيالمر حلة|لثانويةنحو المرشدالطلابيفيمدينةبريده .وق

داستخدمالباحثالمنهجالوصفيالمسحي،وقامباستخدام الاستبيانكأداةلجمعالبياناتمن عينةالدر اسةوكانت من طلابالمر حلة|الثانويةبمدينةبريدهفتمأخذعينةعشو ائيةبلغت ( . ب )

طالبًا،و قدأظهر تالدر اسةالنتائجالتالية: لاتوجدفروقذاتدلالة|إحصائيةفياتجاهاتطلابالمر حلةالثانويةنحو المرشدالطلا بيباختلاف المتغير اتالتالية(العمر ،الصفالدر اسي،التقدير ،مستو لدخلالأسرة)فيثلاثنةأبعادو هياتجاها تهم نحو (دور المرشدالطلابيدور الإرشادالطلابييشكلعام، نحو الأساليبالإرشاديةالمستخدمةفيمو اجهةمشكلاتالطلابمنالم رشدالطلابي).

كما أنهلاتوجدفروقذاتد لالة|إحصائيةقياتجاهاتطلابالمر حلةالثانويةنحو المرشدالطلابيباختلاف المتغير ات(العمر ،الصفالدر اسي،مستو دخلالأسرة)بينماتوجدفروقذاتدلالةةإحصائيةفي اتجاهاتهمباختلافمتغير التقدير ـلاتوجدفروقذاتدلالةإحصائيةفياتجاهاتطلابالمر حلةالثانويةنحو المرشدالطلابياختلا ف المتغير اتالتالية ) العمر ،الصفالدر اسي، التقدير، مستو بذخلأسرة .وبلغالمتوسطالحسابيالعاملإجاباتالمبحوثينو هو مايعر فبالاتجاهال

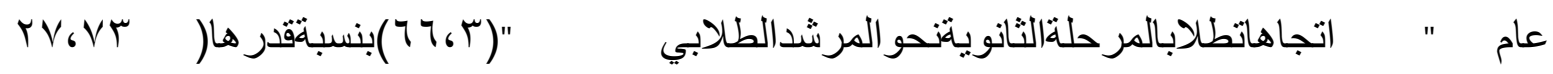
\%) و هينتيجةتعبر عنالاتجاهاتالإيجابيةلأفر ادعينةالدر اسة.

دراسة"عودة" (2009م) بعنوان(أسباب الرسوب الدراسي وعلاجها) وكان الهدف من الدر اسة التعرف على أسباب الرسوب المتعلقة بكل من:الطالب،المدرسة،المنهج الدر اسي،الحالة النفسية للطالب.وقد استخدم الباحث المنهج الوصفي التحليلي. وقدتم اختبار عينة عشوائية من طلاب مدر اس المرحلة الثانوية بمدينة جدة وقدرها ( 180 مفردة ). وكانت أداة الدر اسة : مقياس من إعداد الباحث.ومن أهم نتائج الدراسة أنها حددت أسباب الرسوبمن الأسباب الخاصة بالطالب:صعوبة فهم 
بعض المو اد الدر اسية،المرض المفاجئ أثناء الامتحانات وكثرة الدر اسة،أما الأسباب المدرسية فكانت كالتالي:تأخر استلام الكتب المدرسية واستخدام العقاب كوسيلة وصعوبة أسئلة الامتحانات وكثرة الواجبات المدرسية.ومن الأسباب المتعلقة بالمنهج الدر اسي:صعوبة بعض المواد الدر اسية،طول المنهج،ضعف طرق التدريس. وتمثلت الأسباب النفسية للرسوب في :الخوف من الامتحانات ،وجود مشكلات عاطفية أوضعف الثقة بالنفس،ضعف الدافعية للتعلم،سوء معاملة الو الدين.

دراسة "العنزي"(2004م)بعنوان(دور المرشد الطلابي كمايدركه مديرو المدارس المتوسطة والثانوية

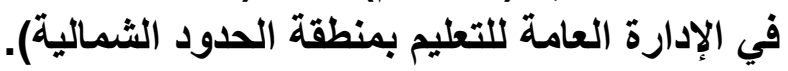
وقد هدفت الدر اسة إلى التعرف على إدراكات مديري المدارس المتوسطة والثانوية بخصوص دور المرشد الطلابي،و التعرف على مدى وجود اختلافات في إدر اكات مديري المدارس المتوسطة عن نظر ائهم مديري المدارس الثانويةوقد اختيرت العينة بطريقة قصدية واستخدم الباحث المنهج الوصفي كما اعتمد على الاستبيان.وكان من أهم نتائجها:أكثر الوظائف يقوم بها المرشد الطلابي كمايدركها مديرو المدارس المتوسطة والثانوية هي:تكريم الطلاب المتفوقين،تشيع الطلاب على الالتز ام الأمثل بالأخلاق الإسلامية،تو عية الطلاب بخطورة مصاحبة أصدقاء السوء يبينما أقل الوظائف التي يقوم بها المرشد الطلابي هي:تطبيق الاختبار ات النفسية المختلفة للطلاب عند الحاجة،تطبيق بعض الاختبار ات لمساعدة الطلاب على التعرف في التعرف على قدر اتهم وميولهم،الإسهام في تكوين اتجاهات إيجابية للطلاب نحو التعليم المهني و الفني.و لاتوجد فروق ذات دلالة إحصائية بين مديري المرحلة المتوسطة والثانوية في إدر اكهم لدور المرشد الطلابي.

(2002)

دراسة"مسلم" (مشكلاتالتعليمالعاممظاهرسلبيةوتطلعاتِايجابيةدر اسةتحليليةلمدركاتعينةمنمديريالمدارسالمتدربينبكليةالتربي تجامعة(الملكسعود) وقدهدفتالدر استةإلى

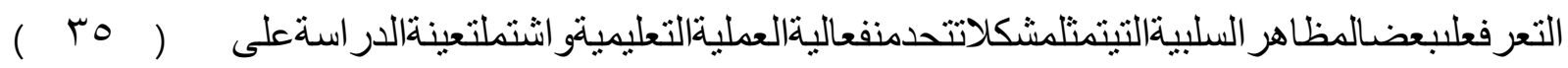
مديرمدرسة(ابتدائي _متوسط_ثانوي) منمناطق تعليميةمختلفةبالمملكة واستخدم الباحث الاستبيان كما اعتمد


النتائج :أنضعفمستو بالتحصيلالدر اسيأكثر المشكلاتبنسبة( 7.85)،ثمانخفاضالدافعيةتلتعلمبنسبة( 77، 17)،وضعفم شار كةأولياء الأمور للمدرسةفيحلمشكلاتأبنائهمبنسبة( ثانياً:الاراسات العربية: 
شملتعينةالدر اسة) TVV طالجًاو طالبةمنالصفالعاشربالأردن،و استخدمالباحتثلاثة مقاييس

مقياسبيئة التعلمالآمنة،مقياسالتفاعلالاجتماعي،ومقياسالدافعيةللتعلم،و أظهر تالنتائجتفوق



دافعيتهملتنعلم.

ثالثاً:(الدراسات الأجنبية:

دراسة "توليز" ( 2010م ) حيث شملت( 30)طالب من طلاب المرحلة الثانوية حيث التحقو الكال

بفصول خاصة تدرس من قبل الباحث،حيث أكمل الطلاب الإستيانات و اليوميات المعدة لهذا

الهدف،وشاركوا في مجموعات التركيز لتحديد ومناقشة إستر اتيجيات التدريس التي يشعرون أن لها تأثيراً

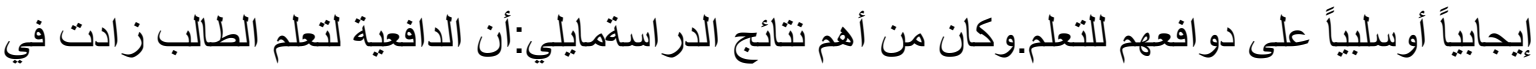
وجود بيئة داعمة داخل الفصول ،وهي الفصول التي تم فيها استخدام مجمو عة متنوعة من الإستر اتيجيات

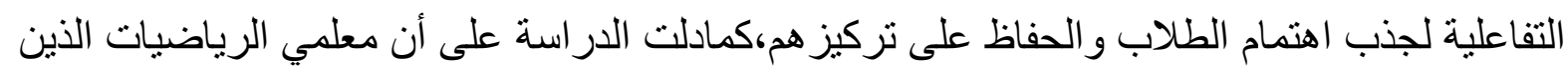
يتبنون خطة أكثر فعالية من أجل زيادة تحفيز الطلاب للتعلم ساعدوا في تحسين تحصيل الطلاب في مادة

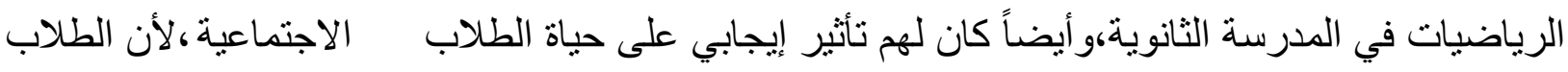

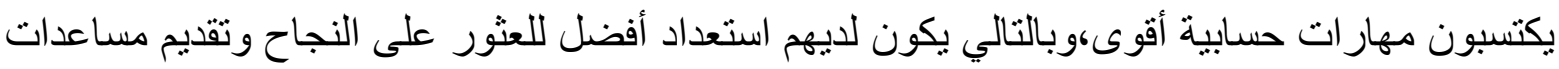

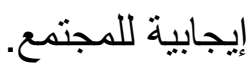

دراسة" تولمان"(2006م)وكانت حول وجود المكافأة كأحد أساليب التعزيز و علاقته بزيادة الدافعية نحو التعلمهوقد هدفت الدراسة إلى التعرف على أساليب التعزيز للطلاب في زيادة التحصيل الدراسي و التعرف

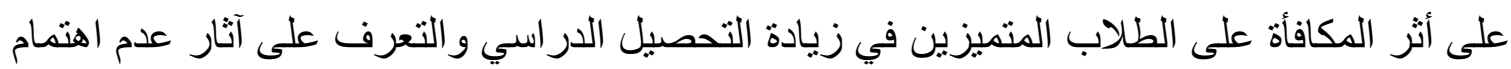
المعلمين بأساليب التعزيز كأحد أساليب زيادة الدافعية نحو التعلم.وحيث قسم العينة إلى مجمو عتين إحداهما ضابطة والأخرى تجريبية ،وكان من أهم نتائجها:

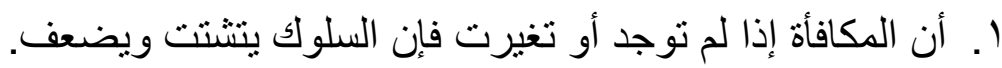
r. أن أساليب التعزيز تحث الطلاب على زيادة الدافعية نحو التعلم.

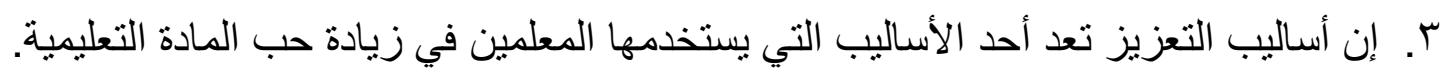
حيثتوصلتنتائجها إلنأنالأسلو بالعلاجيعنطريقالإرشادو التوجيه، دراسة " مونتي" (2003) و إعطاء المعزز ات،و التعليمنخلالالتفاعلالصفيالجماعي، هيأفضلالأساليفيمعالجةالمشاكل السلوكيةو الأكاديمية علنحسو اء. 
دراسة "مايرزوروكا

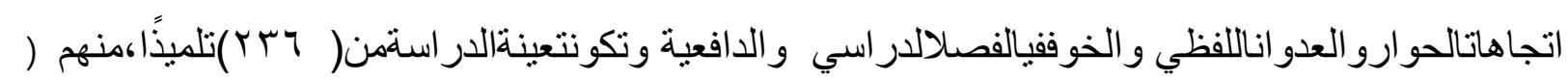

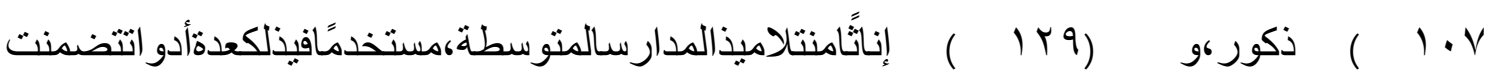
مقياسالمناقشة،و مقياسالعدو اناللفظي،ومقياسدافعيةالتلميذ،و استبانهمناخالتو اصل،وومنالأساليبالإحصائيةمعاملالا رتباط و أظهرتنتائجالدر اسة : وجودعلاقةارتباطيهموجبةبينأسلوبالمناقنتةو الحو ارومناخالفصلالدر اسي المدرك.

مشكلة انخفاض الدافعية للتعلم:

مفهوم انخفاض الا(فعية للتعلم:

الدافعية "حالةداخليةتحركالفردنحو سلوكالفردمايشجِّعالقيامبهعلـاكتساب الج للتعريف بمفهوم انخفاض الدافعية للتعلم ستعرض الباحثة بداية تعريف الدافعية ثم الدافعية للتعلم لنصل أخير اً لمفهوم انخفاض الدافعية للتعلم.و ائزوتجنبالعقاب".( الجغيمان،المعايطة،2009م: ).

حالةداخليةتدفعالطالبةإلبالحرصو المثابرةعلبذلالجهدمنأجلتحقي ق ق

كما أنها تعرف بأنها"

النجاحالدر اسيبدرجة عاليةمنالإتقانو التفو قمنخلالتنظيمالبنيةالمعرفيةللوصو لإلحالة|لاتز انالمعر فيوتحقيقالاس تمتاعبالتعلم"(السليم:2010م:10).

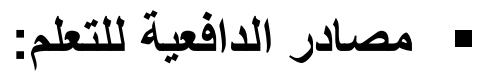

أ - مصادرخارجية :كالمعلمأو إدارةالمدرسةأو أولياءالأمور أوحتبالأقر ان ـ فقديقبل

الطالبعلبالتعلمسعياور اءإرضاء المعلموكسبإعجابهأو إرضاءلو الديهو الحصو لعلنتشجيعماديأو معنويمنها.



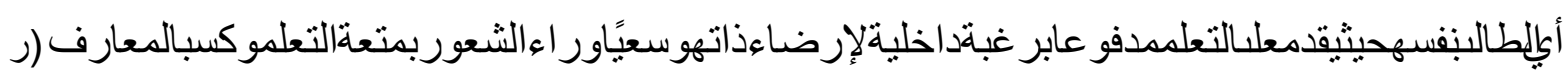

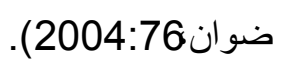

ج - انخفاض الدافعية للتعلم هي"حالثتتنابالطالبأثناء الدر اسةأوقبلهاأوبعدهاتؤديبهإلى التكاسلو عدمبذلالجهدممايفقد هالحماسو الإيجابيةاللاز مةللأداء المدرسينتيجةإهمال

إثباعدافعالتعلم(وزارةالتربيةو التعليم،2007:ب 9 ).

ثانياً:أهمية|لأفعفيعملية|لتعلم

نالدافعيةللتعلمتكادتكو نالمؤشر لفاعليةالتعلمو حيو يتهو تختلفدر جاتتحصيلالطالباتباختلافمستوياتهنو استعد

اداتهن، لذلكيتباينأداء الطالباتبينالضعيفةتحصيليًا، المتوسطة المتفوقةحيثإنقدرةالطالبة علبالتحصيلمرتبطةبتر عت هالدافعة لإنجاز النجاح،و مادامتهذهالتر عةمكتسبةفإنهيمكنتعديلهابحيثزز دادقدرةالطالبة علبالتحصبل(قطامي،2003 


\section{العوامل المؤدية لانخفاض الدافعية للتعلم:}

تتعددالعو املالمؤثرة في الدافعيةللتعلملدالطالبور غبتهفيلإنحصيلالدراسي ،وتتمثل أبرز هذه العو امل فيما يلي: أ ـ العوامل المرتبطة بالمعلم والبيئة الصفية.

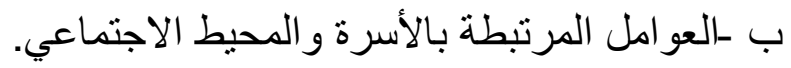



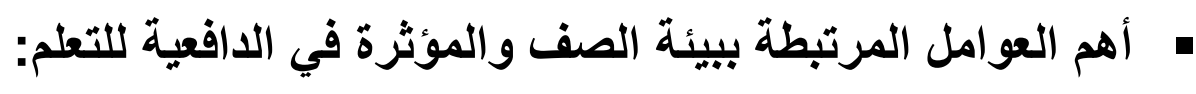

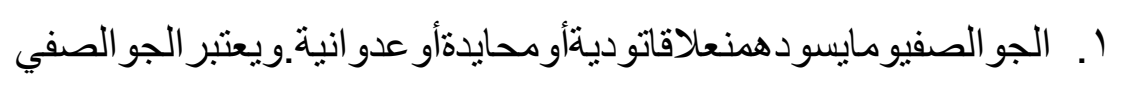

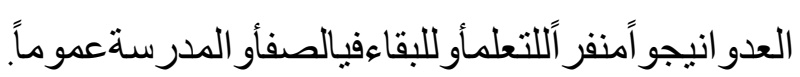
r. التباينالثديدبينالطلبةفيمستو ياتهمالتحصيليةأو الاقتصاديةممايحيلبعضالطلبة إلبطلبة عاجز يالتعلمو عاجزيالخبر اتمقارنةمعأبناء الطبقة|لغنية.

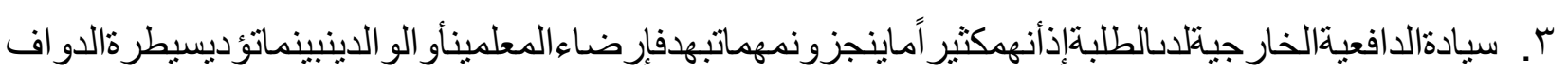

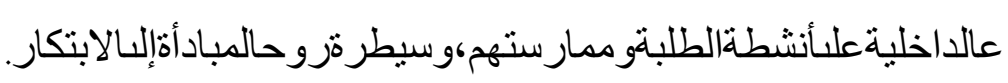
ع. تهوية الصف و إضاءته ومستوى الاهتمام بنظافته،

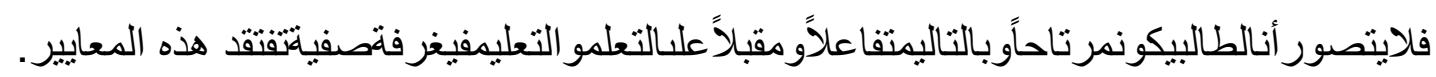



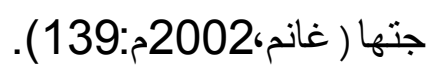

$$
7 \text { 7. تدني الفائدة المباشرة من التعلم.( Bekrman \& Good ، } 1981 \text { ، 317) }
$$

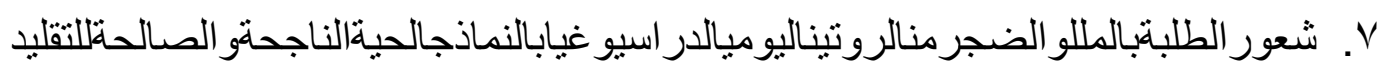
(توقوقطاميو عسس،2002م242) العوامل المرتبطة بالطالب نفسه:


r. . عدماهتمامالطالبيالتعلمبالإضافةإلبعدموضوحميو لهو خططمستقبلهفلايدر كأهمية الاستمر ارفيالتعلمبليهتمفقطبا


r. غيابالنماذجالحية|لناضجةليقلد ها الطلبةويستعينها. ع. الثعوربالضغطالنفسينتيجة|القيو دو القو انينالمفروضة عليهمنالخارج. 0. عدمإنشباعبعضالحاجاتالأساسيةمثل: المأكلو الملبس. (غانم،2002م:145).

ج-العوامل المرتبطة بالأسرة والمحيط الاجتماعي: تنعكس الشكلاتالتيتقعفيالأسرة علالطالبو بالتاليتؤثر علدافعيتهللتعلم ومنتلكالمشكلات: 


$$
\text { r. . . الوضعانالاقتصاديو الاجتماعي(تدنيدخلالأسرةبثكلكبير). }
$$

r. عدم اهتمام الآباءبأبنائهم و استغر اقهمبثؤونهمالخاصةتو مشكلاتهمفلايعبرو اعنأياهتمامبلُهاء الابنفيالمدرسة.

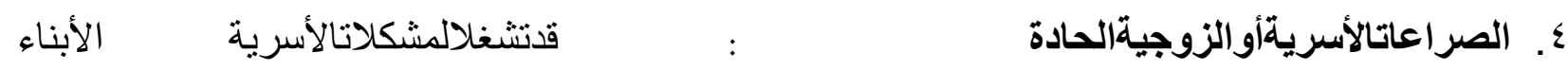

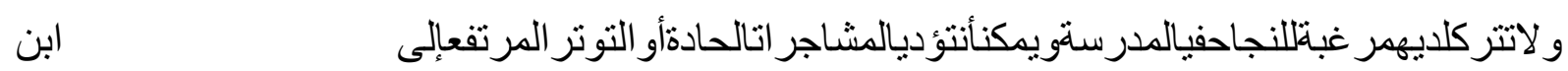
مكتئبفتنقل لأيميللعملالمدرسي.


:يشعر الأبناء المنبوذونباليأسو عدمالكفاءةو الغضبفيستخدمونالضعفالتحصيليو الإهمالكطريقةلانتقاممنالو الدين:

\section{بصض المشكلات الناتجة عن ضعف الدافعية للتعلم:}

هناك العديد من المشكلات الناتجة عن ضعف الدافعية للتعلم و التي تظهر داخل الصف أو خارجه وتأثر سلبا على سير العملية التعليمية ونذكر منها على سبيل المثال لا الحصر :

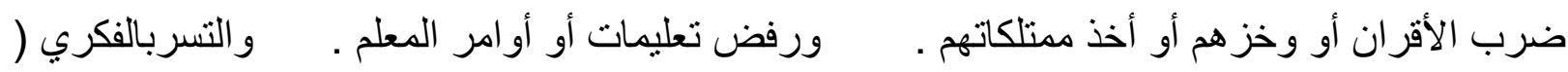

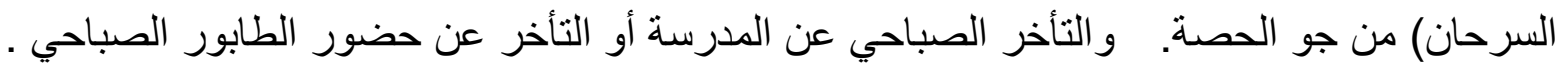

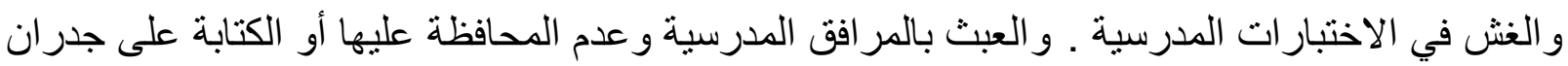
المدرسة (فرج،2006م:84).

\section{تعريف التوجيه والإرشاد :}

التوجيهو الإرشاد "عمليتانمتر ابطتانو متكاملتان،وو همايعبر انعنمعنمشتر كيتضمنالمساعدةفيتغيير السلو كنحو الأفض

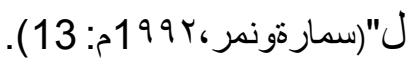
" عمليةمخططة منظمةتهدفإلنمساعدةالطالبلكييفهذاته يعر فالتو جيهو الإرشادبأنه ويعرفقدر اتهو ينميمكانياتهو يحلمشاكلهليصلإلنتحقيقتو افقهالنفسيو الاجتماعي

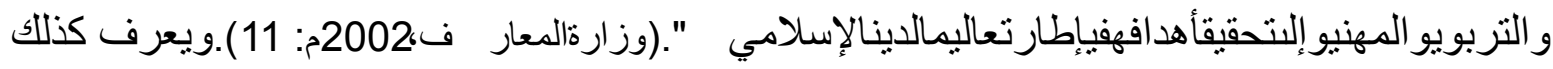
بأنه" عملية بناءة تهدف إلى مساعدة الفرد لكي يفهم ذاته ويدرس شخصيته،هويعرف خبر اته ويحدد مشكلاته

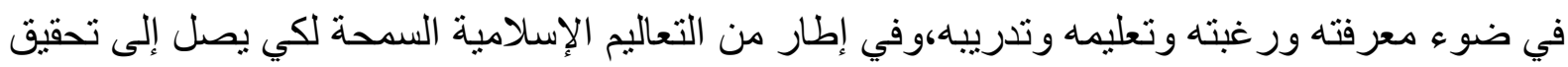

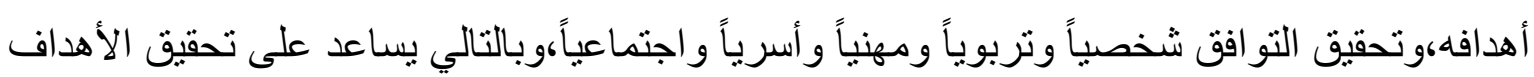

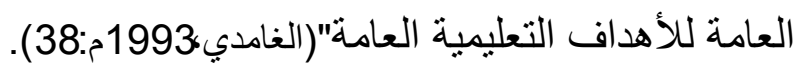


من أهم الأهدافالتي حددتها الإدارة العامة للتوجيه والإرشاد بوزارة التربية والتعليم مايلي:

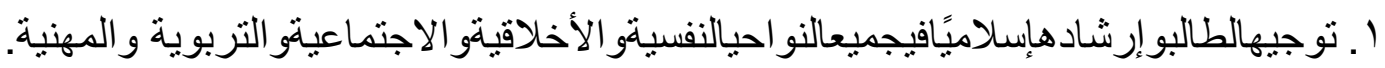
r. مساعدة الطالب على حل مشكلاته بطرق علمية صحيحة. بـ العملعلتو ثيقالعلاقة و التعاون بينالبيتو الددرسة. ع. العمل على اكتثاف قدرات ومواهب الطلاب.

0. توعية المجتمع المدرسي(الطالبو المدرسو المدير) بأهدافومهام التوجيهو الإرشادودور هفيالتربيةو التعليه. 7 ا. إجر اءالبحوثو الدر اساتحولمشكلاتالتعليمفيالمملكة علسبيلالمثنال مشكلةالتسربو إهمالالو اجباتالمدرسيةوتدني الدافعية للتعلم وكثرة الغياب... إلخ V. مساعدة الطلاب على اختيار نوع الدراسة أو المهنة التي تتناسب مع قدر اتهم وميولهم وحاجات

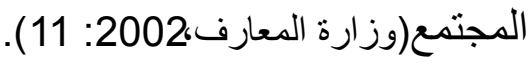


وق أوضحت وزارة المعارف مهام وواجبات المرشد الطلابي كمايلي: 1. إعدادالخطةالعامة|لسنويةلبر امجالتو جيهو الإرشادفيضو ءالتعليماتالمنظمةلذلك و اعتمادهامنمدير المدرسة. r. تبصير المجتمع المدرسي بأهداف التوجيه و الإرشاد وخططه وبر امجه وخدماته لضمان قيام كل عضو بمسؤوليته في تحقيق هذه الأهداف.

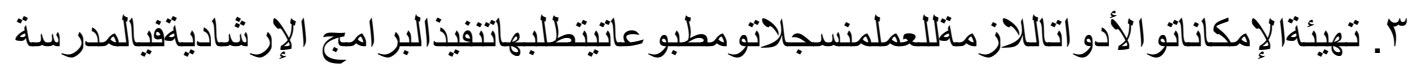
ع. الإسهامفيتشكيلمجلسالمدرسةو لجانالتوجيهو الإرشادور عايةالسلوكو اجتماعاتأولياء أمور الطلابو المعلمينو فقًاللتعليماتالمنظمةلذلكو عقداجتماعاتو متابعةتتفيذتوصياتها وتقويمنتائجها ه. إعدادوتنفيذالبر امجو المشرو عاتالدر اسية|لتيير بالمرشدالطلابيمناسبتهالطلابالمدرسة أوتلكالتيقتتر حهامشر فالتو جيهو الإرشادأومدير المدرسة. 7. تنفيذبر امجالتو جيهو الإرشادوخدماتهالإنمائيةو الوقائيةو العلاجيةو التيتتركز فيالآتي ممساعدةالطالبفياستغلالمالديهمنقدر اتو استعداداتإلأقصسدرجةممكنةفي تحقيقالنمو السو يفيشخصيته. تتمية|لسماتالإيجابيةو تعزيز هالدالطالفيضو عمبادئالدينالإسلاميالحنيف. يتمية|الدافعيةلدالطالبنحو التعليمو الإرتقاءبمستو نطموحه متابعةمسنو بالتحصيلالدر اسيلفئاتالطلابجميعًا متفو قين،متأخريندر اسيًا،معيدينو متكرريالرسوب،متوسطيالتحصيل) . 
-التعر فعلنالطلابمتكرر يالغيابأو الذينيغييونبدونأعذار مقنعةو كذلكالطلاب الذينيتسربو نمنالمدرسةودر اسةالأسبابو العو املالمؤديةإلنذلكبمايسهمفيتو افقهم الدر اسيو الإجتماعيالمنشود.

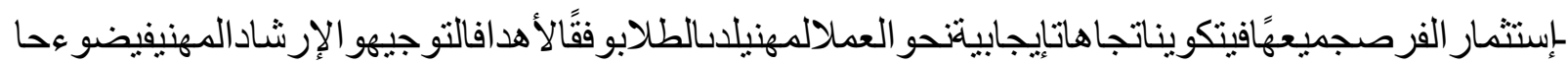
جةالتنميتفيالمجتمع. ـالتعر فعلنالطلابذو يالمو اهبو القدر اتالخاصةور عايتهم. -مساعدةالطالبالمستجدعلالتكيفمعالبيئة المدرسيةوتكويناتجاهاتايجابيةتحو الددرسة. ـالعملعلاكتشافالإعاقاتالمختلفةو الحالاتالخاصةفيو قتمبكر لاتخاذالإجر اءالملائم. ـالعملعلتحقيقمبادئلتو عيةالسليمةفيالجو انبالصحيةو التربويةو النفسية و الاجتماعية. تموثيقالعلاقةبيناليبتو المدرسةوتعزيز هاو استثمار القنو انالمتاحةجميعهابمايحقق رسالة|لدرسة علنيروجهفير عاية|لطالبمنمختلفالجو انب

ـالتعر فعلحاجاتالطلابو مطالبنمو هفيضو وخصائصالنمو لديهمو العملعلى تلبيتها -در اسةحالاتالطلاببجميعانو اعهادر اسية،نفسية،اجتماعية،صحية،اقتصادية

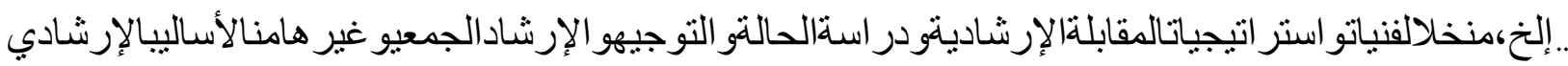

ة مختلفة.

- التعرفعلأحو الالطلابالصحيةو النفسيةو الاجتماعيةو التحصيليةقبلبدء العام الدر اسي،وتحديدمنيحتملأنهمبحاجةإلنخدماتو قائيةقرديةأوجماعية،ول لاسيما الطلابالمستجدينفيكلمر حلةمنالمر احلالثلاث -تصميمالبر امجو الخططالعلاجية|لمبنية علنالدر اسة العلميةللحالاتالفردية و الظو اهر الجماعيةللمشكلاتالسلو كيةو التحصيليةو تتفيذها. -تنمية|القدر انالمعر فيةالذاتيةو الخبر انالعلميةتلمرشدالطلابيو بخاصةفيالجانب المهنيالتطبيقيفيميدانالتربيةو التعليمعامة،وفيمجالالتو جيهو الإرشادخاصةللارتقاءبمستو بأدائه. -بناءعلاقاتمهنيةمثمرةمعالهيئة|الإداريةقو أعضاء هيئة|التدريسميعهمومع

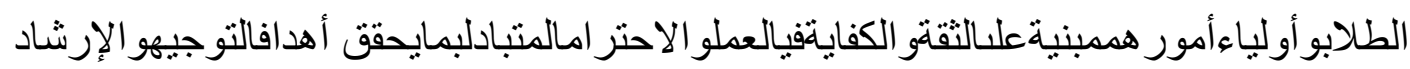

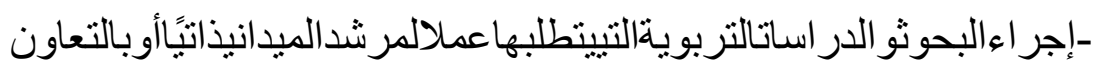
معزملائهالمشرفينبقسمالتوجيهو الإرشاد، أو المرشدينفيالمدارسالأخرى.

أدوار المرشد الطلابي:يمكن للمرشد الطلابي أن يقدم خدماته وفقاً للأدوار التالية:

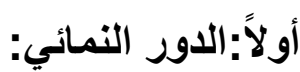

و الهدف من هذا الدور هومساعدة الطلاب على النمو السليم،ويمكن أن يتحقق ذلك عن طريق: 
ا. تنمية دهار ات الطالب عن طريق اكتثافها أولاً،وبالتالي إتاحة الفرصة لهذه القدرات و الإمكانات للنمو

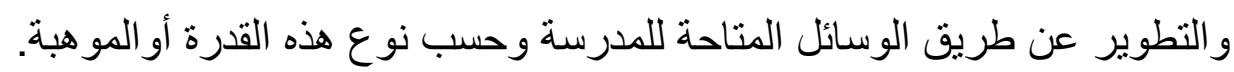


ييحققأعلنمستو دمنالتو افق و الصحة|النفسية.

r. استخدام القدوة ليتمكن الطالب أن يتعلم القيم الحقيقية للمعايير الأخلاقية.

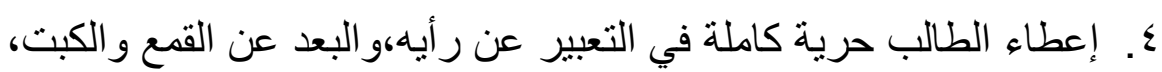

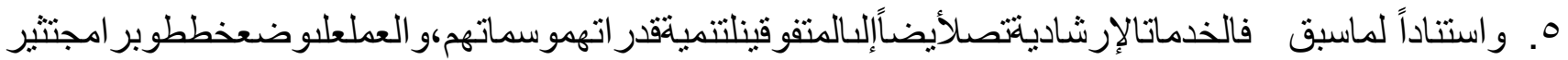
فيهمالقدرة عليالتفكيرو الإبداعو غير ذلك.



يهدف هذا الدور إلى منع حدوث المشكلات للطلاب سواء (صحية،أودر اسية،أو اجتماعية،أونفسيه

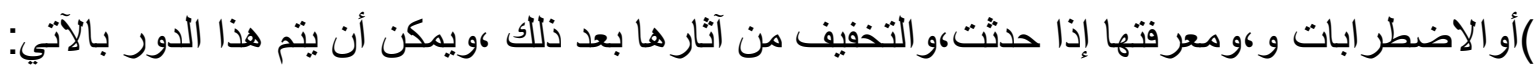
1. التوعية التي يجب نشرها بين الطلاب عن طريق النشرات و الندوات و الدحاضر ات و الملصقات و التي تهدف

إلى التعريف بأسباب المشكلة أو الإضطر ابات و أهم الوسائل لتجنبها. r. ت. تعريفالطلاببأنظمةالدر اسة،وقو انينه،و إلنمايقيهمالو قو عفيمشكلاتصحية، أودر اسية، أو اجتماعية،أو نفسيه. r. التو عية بالعاداتالصحية|لسليمةفيالمأكلو المسكنو الأجو اءالمناسبةلللمذاكرة. ع. الكثفالصحيالدوريلعمو مالطلاب،و متابعةالحالاتالمرضية. و الحذرمنالأمر اضالمعديةالمبكرة. 0. البحث عن السلوكيات السيئة و المشكلات ومحاولة اكتثافها مبكر ا. 7. التعاون مع الجهات ذات العلاقة(عن طريق قسم التوجيه والإرشاد الطلاب بالمنطقة )في إيجاد الحلول

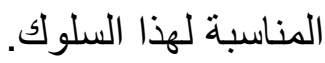

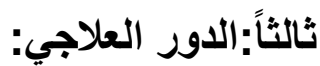
يهدف الدور العلاجي إلى مساعدة الطالب على العودة إلى حالة التو افق ويمكن أن يتم ذلك عن طريق:

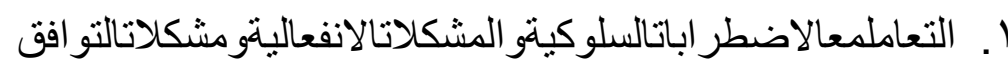




المرشدمعفريقالعلاجمنأطباءنفسيينو غير همفيمعالجةالاضطر اباتالثديدة. r. استثمارطاقات الفردوتنميتهاللتغلبعلالعقباتالتيتسببلهالمشاكل و تختلفمساعدةالمرشدباختلافتشخيصالحالة،فتقديمالمعو نةقو المساعدثيقو معلهزا التشخيصللمشكلةو اكتشافنقاطالض عفأو لاثميتدر جفي محاو لتتصحيحهاو تقديمالمساعدة( الشهري،2003م:13-14). 
ومن هنا تبدو أهمية دور المرشدة الطلابية عندما تقوم بأدو ار ها المتكاملة في تقديم الخدمات الإنمائية و الوقائية و العلاجية على النحو الذي سبق إيضاحه في المر احل المختلفة مع تعديل وتطوير ما يلزم و العملعلبناء وتنميةتشخصي اتهن تطوير ه6بما يتفق و احتياجات وظروف الطالبات في كل مرحلة وفقالمنهجالإسلامي.

\section{منهج و إجراعات الدراسة:}

أولا: منهج الاراسة:تحقيقا لأهداف الدراسة استخدمت الباحثة المنهج الوصفي " الذي يعتمد على "در اسة الظاهرة كماتوجد في الو اقع

ثانياً: مجتمع الدراسة : يتمثل مجتمع الدراسة في طالبات المرحلة الثانوية في المدارس الحكومية بمدينة جدة و عددها ( 255) مدرسة موزعة على جنوبمدينة جدة. ( موقع وزارة التربية والتعليم،دليل المدارس الإلكتروني بمدينة جدة، 1435هـ).

ثالثثاً: عينة الار اسةة: تم اختيار عينة الدر اسة بطريقة العينة العشوائية البسيطةـ من أفر اد مجتمع الدر اسة من طالبات المرحلة الثانوية حيث تم تحديد خمس مدارس ثانوية حكومية بمدينة جدة بطريقة عشو ائية و هي مدارس (الثانوية الثالثة و الستون، و الثانوية السابعة و الأربعون، و الثانوية الثانية و الخمسون، و الثانوية الأربعون، الثانوية الخامسة والأربعون) و عدد الطالبات بتلك المدارس ( 2586) طالبة.وتم توزيع ( 250) استبانه على عينة عشوائية من طالبات تلك المدارس، وكانت الاستبيانات المستردة ( 226) تم استبعاد ( 8) استبيانات منها لعدم اكتمالها وأصبح عدد الاستبيانات المكتملة و الصالحة للتحليل (218) استبانه تمثل أفر اد عينة الدراسة من طالبات المرحلة الثانوية الحكومية بمدينة جدة. رابعاً: أداة الدراسة (الاستبانة):قامت الباحث ببناء أداة الدراسة وهي الاستبانة وقد احتوت الاستبانة في صورتها النهائية على جز أين رئيسيين الجزء الأول: عبارة عن البيانات الأولية لأفر اد عينة الدراسة الجزء الثاني: محاور الاستبانة، ويتكون من محورين رئيسيين هما: المحور الأول: العوامل المدرسية المؤدية لانخفاض الدافعية للتعلم لدى طالبات المرحلة الثانوية، ويتكون من بعدين هما: ـالبعد الأول: العو امل المرتبطة بالمعلمة ، ويتكون من (11) عبارة ـالبعد الثاني: العو امل المرتبطة بالبيئة الصفية ، ويتكون من (11) عبارة المحور الثاني: دور المرشدة الطلابية في حل مشكلة انخفاض دافعية طالبات المرحلة الثانوية للتعلم ، ويتكون من (18) عبارة ـ صدق أداة الدراسة:من أجل التأكد من صدق الاستبانة قامت الباحثة باستخدام الطرق التالية: 
1) الصدق الظاهري : تم عرض الاستبانة في صورتها الأولية على 8 من المحكمين من ذوي

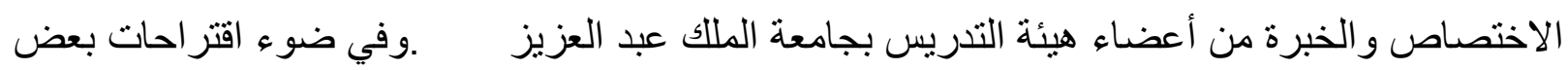

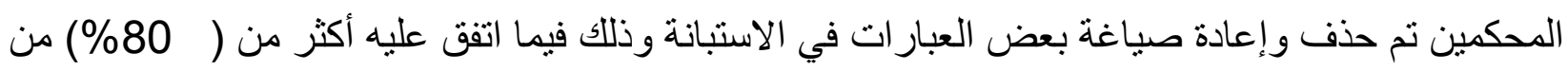

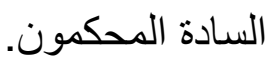
2) صدق الاتساق الاخلي :تم توزيع الاستبانة على عينة استطلاعية مكونة من (30) طالبة من خارج عينة الدراسة بهدف التحقق من صدق الاتساق الداخلي لعبار ات الاستبانة، ومن ثم قامت الباحثة بحساب البابه

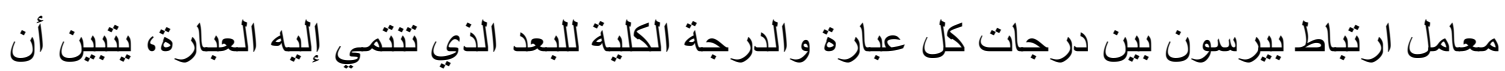

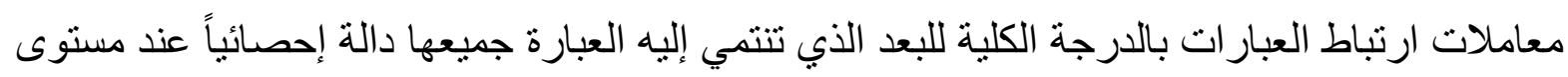
دلالة (0.01)، وجاءت جميع قيم معاملات الارتباط قيم عالية حيث تراوحت في البعد الأول من المحور

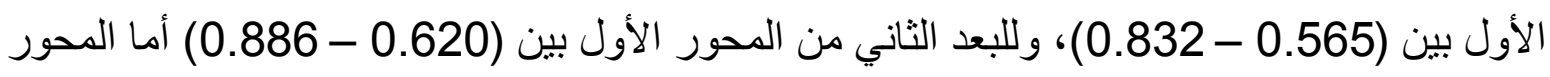

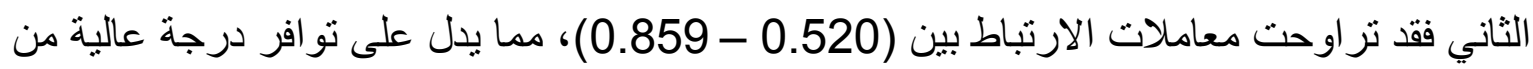
صدق الاتساق الداخلي للاستبانة.

ـ ـ ثبات أداة الدراسة: تم التأكد من ثبات الاستبانة من خلال حساب ثبات الاتساق الداخلي للعبارات باستخدام معادلة كرونباخ ألفا، وجاءت النتائج أن جميع قيم معاملات الثبات لـحاور الاستبانة كانت قيم

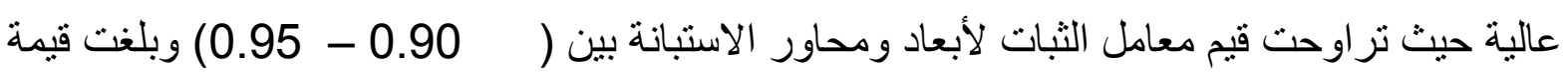

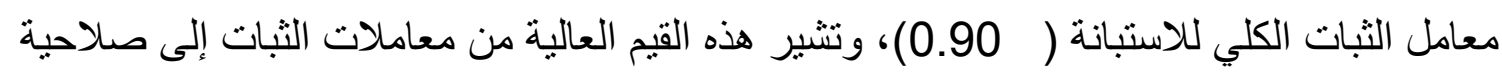
الاستبانة للنطبيق و إمكانية الاعتماد على نتائجها 

أن أغلب أفراد عينة الدراسة من طالبات المرحلة الثانوية بالصف (الثاني الثانوي) بنسبة ( 41.7\%)، يليهن طالبات الصف (الثالث الثانوي) بنسبة ( 29.8\%)، وكانت أقل نسبة لطالبات الصف (الأول الثانوي) حيث بلغت نسبتهن (28.4\%) من إجمالي أفر اد عينة الدراسة.


أغلب أفر اد عينة الدراسة من طالبات المرحلة الثنانوية تخصصهن (علمي) بنسبة ( 43.2\%)، بلئهن كل من الطالبات اللاتي تخصصهن (أدبي) وطالبات الصف الأول الثانوي اللاتي تخصصهن (عام) بنسبة (\%28.4) 3) توزيع أفراد عينة الاراسة وفقاً للحالة التعليمية للأب: أن أغلب أفر اد عينة الدر اسة من طالبات المرحلة الثانوية مؤهل آبائهن (جامعي فما فوق) بنسبة آناتية

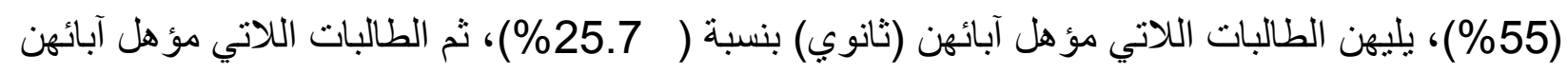

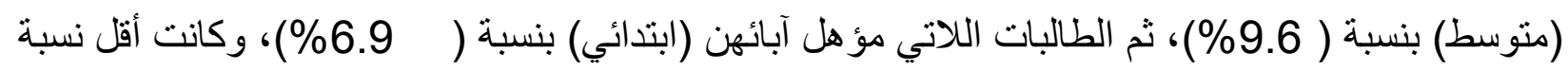

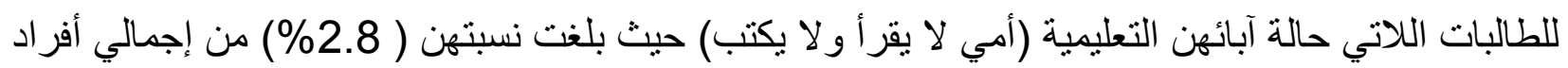
عينة الدراسة.

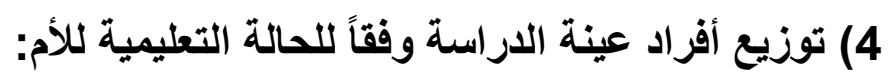

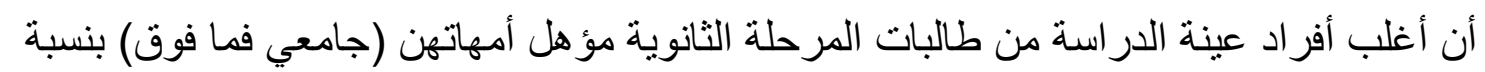

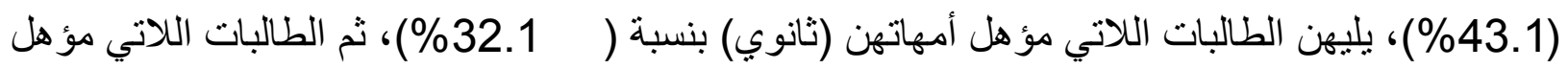

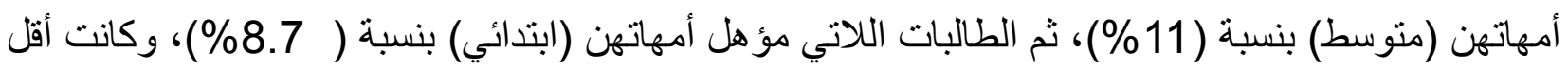

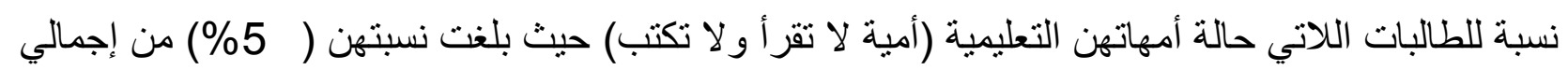
أفراد عينة الدراسة.



إجابة التساؤل الأول وللإجابة على هذا السؤال، فقد تم حساب التكرارات والنسب المئوية لاستجابات أفراد عينة الدراسة على عبار ات البعد الأول من المحور الأول (العو امل المدرسية المرتبطة بالمعلمة والمؤدية لانخفاض

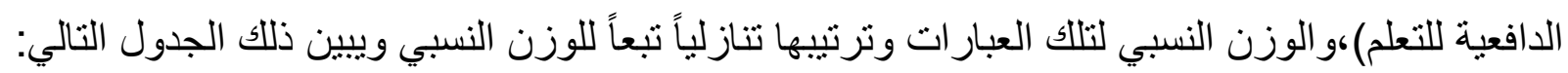

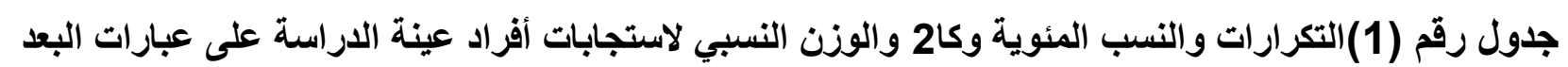

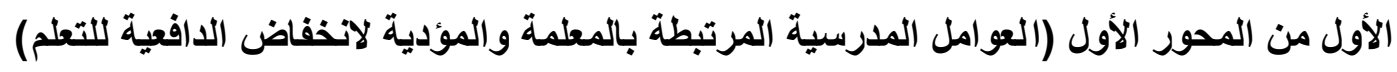
مرتبة تنازليا تبعا للوزن النسبي 


\begin{tabular}{|c|c|c|c|c|c|c|c|c|c|c|c|c|c|c|c|c|}
\hline \multirow{3}{*}{ الترتيب } & \multirow{3}{*}{ | لدرجة } & \multirow{3}{*}{ 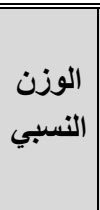 } & \multirow{3}{*}{ | الدالة | مستوى | } & \multirow{3}{*}{$\mid$\begin{tabular}{c|} 
قيمة \\
$(2 \leq 5)$
\end{tabular}} & \multicolumn{10}{|c|}{ التكرارات والنسب المئوية (ن = 218) } & \multirow{3}{*}{ 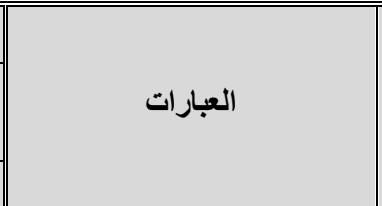 } & \multirow{3}{*}{ 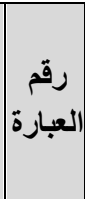 } \\
\hline & & & & & \multicolumn{2}{|c|}{ |لا أوافق بشدة | ل | } & \multicolumn{2}{|c|}{ لا أوافق } & \multicolumn{2}{|c|}{ أو أو ما إلى } & \multicolumn{2}{|c|}{ أوافق } & \multicolumn{2}{|c|}{ أوافق بثدة } & & \\
\hline & & & & & $\%$ & $ت$ & $\%$ & $ت$ & $\%$ & $ت$ & $\%$ & $ت$ & $\%$ & $ت$ & & \\
\hline 1 & 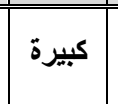 & 3.57 & 0.01 & 42.78 & 7.3 & 16 & 11.9 & 26 & 27.1 & 59 & 23.4 & 51 & 30.3 & 66 & |ظروف الطالبة المتقار المرونة ومراعاة & 7 \\
\hline 2 &  & 3.49 & 0.01 & 49.48 & $\mid 18.3$ & 40 & 9.2 & 20 & 15.1 & 33 & 19.7 & 43 & 37.6 & 82 & |لضبط نظام الصفلة أسلوب التهايد & 10 \\
\hline 3 & 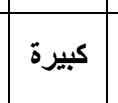 & 3.47 & 0.01 & 52.96 & 6.9 & 15 & 14.7 & 32 & 33.0 & 72 & 15.6 & 34 & 29.8 & 65 & 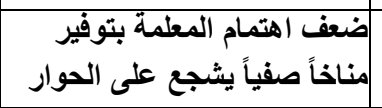 & 8 \\
\hline 4 & كبيرة & 3.41 & 0.01 & 31.77 & 6.9 & 15 & 20.2 & 44 & 26.6 & 58 & 17.9 & 39 & 28.4 & 62 & |حوافز مغوية (كالثناء والمدامح) & 5 \\
\hline 5 & متوسطة & 3.39 & 0.01 & 30.72 & 8.3 & 18 & 16.5 & 36 & 29.4 & 64 & 19.3 & 42 & 26.6 & 58 & | الفردية براعاة الطعلمة للفروق & 6 \\
\hline 6 & متوسطة & 3.38 & 0.01 & 22.23 & $\mid 10.6$ & 23 & 14.2 & 31 & 26.6 & 58 & 23.9 & 52 & 24.8 & 54 & |التتقين المعلمة على أسلوب & 2 \\
\hline 7 & متوسطة & 3.36 & 0.01 & 56.82 & $\mid 13.8$ & 30 & 9.6 & 21 & 33.9 & 74 & 11.9 & 26 & 30.7 & 67 & | صعوبة الأسئلة التي تضعها & 4 \\
\hline 8 & متوسطة & 3.19 & 0.01 & 55.67 & 4.1 & 9 & 25.2 & 55 & 34.9 & 76 & 18.8 & 41 & 17 & 37 & |المقرم تلزويدالطالبات بأهداف & 1 \\
\hline 9 & متوسط & 3.15 & 0.01 & 14.11 & $\mid 14.2$ & 31 & 18.8 & 41 & 28 & 61 & 15.6 & 34 & 23.4 & 51 & | عالم حرص المعلمة على فهم & 3 \\
\hline 10 & متوسط & 3.03 & 0.01 & 13.74 & 20.6 & 45 & 21.6 & 47 & 19.3 & 42 & 11.5 & 25 & 27.1 & 59 & 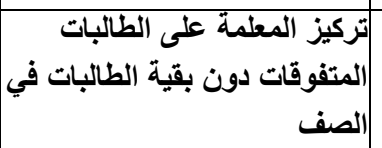 & 11 \\
\hline \multirow[t]{2}{*}{11} & متوسط & 2.85 & 0.01 & 25.67 & $\mid$\begin{tabular}{|l|}
$\mid 17.4$ \\
\end{tabular} & 38 & 21.6 & 47 & 32.6 & 71 & 15.1 & 33 & 13.3 & 29 & |لعدرمية الصفية الثبة في الأنثطة & 9 \\
\hline & متوسطة & 3.30 & & \multicolumn{13}{|c|}{ المتوسط العام للعوامل المدرسية المرتبطة بالمعلمة والمؤدية لانخفاض الدافعية للتعلم لدى طالبات المرحلة الثانويةً } \\
\hline
\end{tabular}

يتضح من الجدول السابق أنه نوجد فروق دالة إحصائياً بين استجابات عينة الدراسة على عبار ات البعد الأول من المحور الأول (العو امل المدرسية المرتبطة بالمعلمة و المؤدية لانخفاض الدافعية للتعلم)،حيث تراوحت قيم (كا2) لدلالة الفروق بين الاستجابات للبيانات الرنبية بين ( 13.74 - 56.82) وجميعها دالة إحصائياً عند

مستوى دلالة (0.01).

وجاء المتوسط العام للعو امل المدرسية المرتبطة بالمعلمة والمؤدية لانخفاض الدافعية للتعلم لاى طالبات المرحلة الثانوية بوزن نسبي (3.30) مما يدل على درجة موافقة (متوسطة) من وجهة نظر الطالبات على تللك العو امل ككل.

وبالنظر إلى الاستجابة صاحبة التكرار الأكبر في كل عبارة من عبار ات البعد الأول من المحور الأول يتضح من الجدول أن الفروق كانت دالة لصالح الاستجابة (أو افق بشدة) بكل من العبار ات ذات الأرقام ( 8)، وجاءت الفروق دالة لصالح الاستجابة (أوافق إلى حد ما) لكل من العبار ات (1، 2، 3، 4، 6، 11، 9). وجاء المتوسط العام للعو امل المدرسية المرتبطة بالمعلمة والمؤدية لانخفاض الدافعية للتعلم لاى طالبات المرحلة الثانوية بوزن نسبي (3.30) مما يدل على درجة موافقة (متوسطة) من وجهة نظر الطالبات على تللك العو امل ككل. 
وجاءت أكثر العو امل المدرسية المرتبطة بالمعلمة والمؤدية لانخفاض الدافعية للتعلم لدى طالبات المرحلة الثانوية من وجهة نظر هن أربعه عو امل و التي جاء وزنها النسبي بقيمة أكبر من ( 3.4) مما يمثل درجة المو افقة (أوافق) من وجهة نظر الطالبات وتللك العبار ات هي: ـالعبارة رقم 7 (افتقار المعلمة للمرونة ومراعاة ظروف الطالبة ) والتي جاءت في الترتيب الأول بوزن نسبي (3.57) ـالعبارة رقم 10 (استخذام المعلمة أسلوب التهديد لضبط نظام الصف) و التي جاءت في الترتيب الثاني بوزن

ـالعبارة رقم 8 (ضعف اهتمام المعلمة بتوفير مناخاً صفياً يشجع على الحوار ) و التي جاءت في الترتيب الثالث بوزن نسبي (3.47) بينما جاءت باقي عبار ات هذا البعد بوزن نسبي بتر اوح بين ( 3.39 - 2.85) وهو يمثل درجة المو افقة (أو افق إلى حد ما) من وجهة نظر الطالبات وجاء ترتيب تلك العبار ات تنازليا تبعا للوزن النسبي كما يلي: العبارة رقم 6 ( عدم مراعاة المعلمة للقروق الفردية بين الطالبات) و التي جاءت في الترتيب الخامس بوزن نسبي (3.39)

العبارة رقم 2 (اعثماد المعلمة على أسلوب التلقين) والتي جاءت في الترتيب السادس بوزن نسبي (3.38) العبارة رقم 4 (صعوبة الأسئلة التي تضعها المعلمة) و التي جاءت في الترتيب السابع بوزن نسبي (3.36) كما اتفقت مع دراسة"الرافعي"( 2009)حيث أكدت على أثر أسلوب التعلم على مستوى الدافعية للتعلم و التحصيل الأكاديمي.واتفقت مع دراسة"عودة"(2009) كذلك دراسة"تولمان"(2006). إجابة التساؤل الثاني وللإجابة على هذا السؤال، وترتيبها تنازلياً تبعاً للوزن النسبي ويبين ذلك الجدول التالي جدول رقم (2) التكرارات والنسب المئوية وكا2 والوزن النسبي لاستجابات أفراد عينة الدراسة على عبارات البعد الثاني من المحور الأول (العوامل المدرسية المرتبطة بالبيئة الصفية والمؤدية لانخفاض الا(فعية للتعلم)مرتبة تنازليا تبعا للوزن النسبي

\begin{tabular}{|c|c|c|c|c|c|c|c|c|c|c|c|c|c|c|c|c|}
\hline \multirow{3}{*}{ 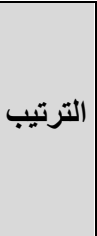 } & \multirow{3}{*}{ لدوجة } & \multirow{3}{*}{ النسبي } & \multirow{3}{*}{ | الدلالة } & \multirow{3}{*}{ قيمة } & \multicolumn{10}{|c|}{ التكرارات والنسب المئويةٌ (ن = 218) } & \multirow{3}{*}{ 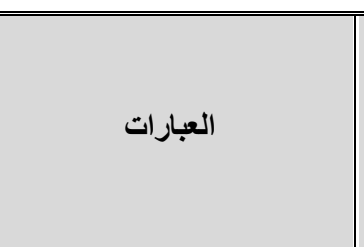 } & \multirow{3}{*}{ p } \\
\hline & & & & & \multicolumn{2}{|c|}{ لا أوافق بشدة } & \multicolumn{2}{|c|}{ لا لاوافق } & \multicolumn{2}{|c|}{ أوافق إلى حـ } & \multicolumn{2}{|c|}{ 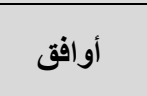 } & \multicolumn{2}{|c|}{ أوافق بشدة } & & \\
\hline & & & & & $\%$ & $ت$ & $\%$ & $ت$ & $\%$ & $ت$ & $\%$ & $ت$ & $\%$ & $ت$ & & \\
\hline 1 & كبيرة & 3.78 & 0.01 & 86.63 & 7.8 & 17 & 10.1 & 22 & 22.0 & 48 & 17.0 & 37 & 43.1 & 94 & |تعليمية حديثة تجهيز الفصول بوسائل & 5 \\
\hline 2 & كبيرة & 3.73 & 0.01 & 85.53 & 6.4 & 14 & 10.1 & 22 & 28.0 & 61 & 15.1 & 33 & 40.4 & 88 & |الصفية مع اهتمامست الطالبات & 7 \\
\hline 3 & كبيرة & 3.57 & 0.01 & 55.35 & 11.9 & 26 & 13.3 & 29 & 19.7 & 43 & 15.6 & 34 & 39.4 & 86 & تهوية الصـف غير الجيدة & 4 \\
\hline 4 & كبيرة & 3.55 & 0.01 & 40.85 & 8.7 & 19 & 13.3 & 29 & 25.7 & 56 & 19.3 & 42 & 33.0 & 72 & |الفوضى والإزعاج داخل الصف & 10 \\
\hline 5 & كبيرة & 3.47 & \begin{tabular}{|l|l|}
0.01 \\
\end{tabular} & 35.72 & 8.3 & 18 & 17.4 & 38 & 25.2 & 55 & 17.0 & 37 & 32.1 & 70 & ضيق مساحة الصف & 6 \\
\hline
\end{tabular}




\begin{tabular}{|c|c|c|c|c|c|c|c|c|c|c|c|c|c|c|c|c|}
\hline 6 & | كبيرة & 3.47 & 0.01 & 39.16 & 9.2 & 20 & 17.0 & 37 & 25.2 & 55 & 15.1 & 33 & 33.5 & 73 & | غالباب جو التنافس الإيجابي بين & 11 \\
\hline 7 & كبيز & 43 & 0.01 & 35.76 & 13.3 & 29 & 17.0 & 37 & 8.8 & 41 & 15.1 & 33 & 35.8 & 78 & ضعف الاهتمام بنظافة الصف & 3 \\
\hline 8 & متوسطن & 3.23 & 0.01 & 35.49 & 11.0 & 24 & 22.0 & 48 & 28.4 & 62 & 10.1 & 22 & 28.4 & 62 & |غياب مشاعر الاحترام والمودة & 8 \\
\hline 9 & |متوسطة & 3.15 & 0.01 & 21.13 & 10.1 & 22 & 25.7 & 56 & 26.1 & 57 & 15.6 & 34 & 22.5 & 49 & كثرة أعاد الطالبات في الصف & 1 \\
\hline 10 & |متوسطة & 3.13 & 0.01 & |22.69 & 10.1 & 22 & 25.7 & 56 & 27.1 & 59 & 15.1 & 33 & 22.0 & 48 & | علدم توفر ركن اولوحة لعر ض| & 9 \\
\hline \multirow[t]{2}{*}{11} & متوسطة & 2.92 & 0.01 & \begin{tabular}{|l|}
24.62 \\
\end{tabular} & 16.5 & 36 & 31.2 & 68 & 18.8 & 41 & 11.0 & 24 & 22.5 & 49 & 20 |لفوضع الصف في مكان قريب من & \\
\hline & | كبيرة & 3.40 & & & & & & & & & & & & & & \\
\hline
\end{tabular}

يتضح من الجدول السابق أنه توجد فروق دالة إحصائياً بين استجابات عينة الدراسة على عبار ات البعد الثاني من المحور الأول (العو امل المدرسية المرتبطة بالبيئة الصفية و المؤدية لانخفاض الدافعية للتعلم )، حيث تراوحت قيم (كا2) لدلالة الفروق بين الاستجابات للبيانات الرتبية بين ( 21.13 - 86.63) وجميعها دالة إحصائياً عند مستوى دلالة (0.01).

وبالنظر إلى الاستجابة صاحبة التكر ار الأكبر في كل عبارة من عبار ات البعد الثاني من المحور الأول يتضح من الجدول أن الفروق كانت دالة لصالح الاستجابة (أو افق بشدة) بكل من العبار ات ذات الأرقام (3، 4، 5، 6، 7، 8، 10، 11)، وجاءت الفروق دالة لصالح الاستجابة (أو افق إلى حد ما) لكل من العبارات (1، 9) بينما جاءت الفروق دالة لصالح الاستجابة (لا أوافق) للعبارة رقم ( 2) .وجاء المتوسط العام للعو امل المدرسية المرتبطة بالبيئة الصفية والمؤدية لانخفاض الدافعية للتعلم لدى طالبات المرحلة الثانوية بوزن نسبي (3.40) مما يدل على درجة موافقة (كبيرة) من وجهة نظر الطالبات على تللك العوامل ككل. وجاءت أكثر العو امل المدرسية المرتبطة بالبيئة الصفية والمؤدية لانخفاض الدافعية للتعلم لدى طالبات المرحلة الثانوية من وجهة نظر هن سبعة عو امل والتي جاء وزنها النسبي بقيمة أكبر من ( 3.4) مما يمثل درجة المو افقة (أو افق) من وجهة نظر الطالبات وتللك العبار ات هي:

ـالعبارة رقم 5 (عدم تجهيز الفصول بوسائل تعليمية حديثة ) و التي جاءت في الترتيب الأول بوزن نسبي

ـالعبارة رقم 7 ( عدم توافق الأنثطة المدرسية الصفية مع اهتمامات الطالبات ) والتي جاءت في الترتيب الثاني بوزن نسبي (3.73)

ـالعبارة رقم 4 (تهوية الصـف غير الجيذة) و التي جاءت في الترنيب الثالث بوزن نسبي (3.57) بينما جاءت باقي عبار ات هذا البعد بوزن نسبي يتر اوح بين ( 3.23 - 2.92) وهو يمثل درجة الموافقة (أو افق إلى حد ما) من وجهة نظر الطالبات وجاء ترتيب تلك العبار ات تنازليا تبعا للوزن النسبي كما يلي: 
•العبارة رقم 8 (غياب مشاعر الاحترام والمودة داخل الصف) و التي جاءت في الترتيب الثامن بوزن نسبي

ـالعبارة رقم 1 (كثرة أعداد الطالبات في الصف) و التي جاءت في الترتيب التاسع بوزن نسبي (3.15)

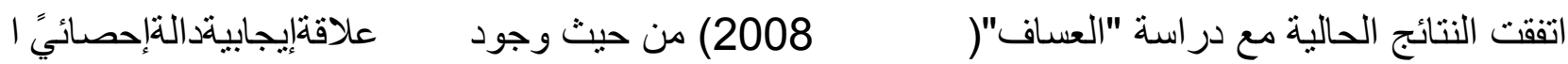

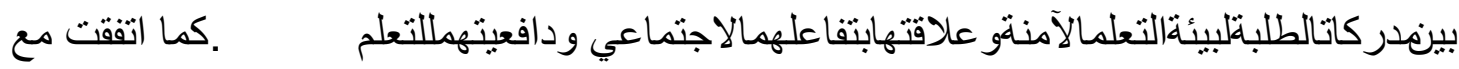
در اسة"العكايثي"(2006).كماتفقت مع در اسة"توليز"(2010) في أن الدافعية لتعلم الطالب زادت في وجود



إجابة التساؤل الثالث ولإجابة على هذا السؤال، فقد نم حساب التكرارات والنسب المئوية لاستجابات أفراد عينة الدراسة على عبار ات المحور الثاني وترتيبها تنازلياً تبعاً للوزن النسبي وييين ذلك الجدول التالي : جدول رقم (3)التكرارات والنسب المئوية وكا2 والوزن النسبي لاستجابات أفراد عينة الدراسة على عبارات المحور الثاني (دور المرشدة الطلابية في حل مشكلة انخفاض الدافعية للتعلم)مرتبة تنازليا تبعا للوزن النسبي

\begin{tabular}{|c|c|c|c|c|c|c|c|c|c|c|c|c|c|c|c|c|}
\hline \multirow{3}{*}{ الترتيب } & \multirow{3}{*}{ الموافقة } & \multirow{3}{*}{ 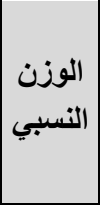 } & \multirow{3}{*}{ الدالة } & \multirow{3}{*}{ ق } & \multicolumn{10}{|c|}{ التكرارات والنسب المئوية (ن = 218) } & \multirow{3}{*}{ 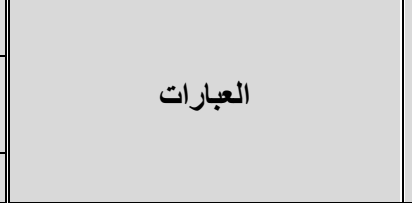 } & \multirow{3}{*}{ p } \\
\hline & & & & & \multicolumn{2}{|c|}{ |لا أوافق بشدة } & \multicolumn{2}{|c|}{ لا أوافق } & \multicolumn{2}{|c|}{ أوافق إلى حـا } & \multicolumn{2}{|c|}{ 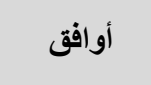 } & \multicolumn{2}{|c|}{ أو افق بشدة } & & \\
\hline & & & & & $\%$ & $ت$ & $\%$ & $ت$ & $\%$ & $ت$ & $\%$ & $ت$ & $\%$ & $ت$ & & \\
\hline 1 & 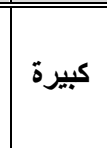 & 3.78 & 0.01 & 73.10 & 6.9 & 15 & 12.8 & 28 & 15.1 & 33 & 25.2 & 55 & 39.9 & 87 &  & 1 \\
\hline 2 & 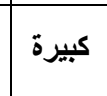 & 3.71 & 0.01 & 69.89 & 6.9 & 15 & 9.6 & 21 & 27.1 & 59 & 18.8 & 41 & 37.6 & 82 & | تلطالبات المتفوقات الطلابية في تكريم | & 15 \\
\hline 3 & كبيرة & 3.69 & 0.01 & 54.84 & 8.7 & 19 & 10.6 & 23 & $\mid 19.7$ & 43 & 24.8 & 54 & 36.2 & 79 & |تلفظع المرشدة الطلابية وقوع الطنة الطنة & 5 \\
\hline 4 & كبيرة & 3.58 & 0.01 & 41.95 & 8.3 & 18 & 15.1 & 33 & 21.6 & 47 & 20.2 & 44 & 34.9 & 76 & |تقوم المرشدة الطلابية بشرح & 17 \\
\hline 5 & كبيرة & 3.54 & 0.01 & 52.87 & 4.6 & 10 & 12.8 & 28 & 31.7 & 69 & 26.1 & 57 & 24.8 & 54 & التتابع المرشدة الطلابية نتائج & 3 \\
\hline 6 & | كبيرة & 3.51 & 0.01 & 31.17 & 8.7 & 19 & 16.1 & 35 & 22.5 & 49 & 21.1 & 46 & 31.7 & 69 & 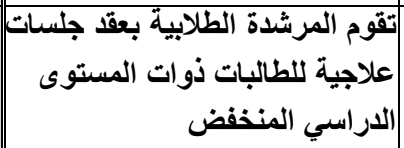 & 11 \\
\hline 7 & كبيرة & 3.45 & 0.01 & 41.50 & 4.1 & 9 & 18.3 & 40 & 29.8 & 65 & 23.9 & 52 & 23.9 & 52 & 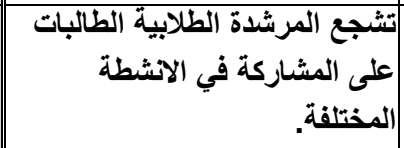 & 14 \\
\hline 8 & كبيرة & 3.44 & 0.01 & 36.27 & 5.0 & 11 & 20.2 & 44 & 22.9 & 50 & 29.8 & 65 & 22.0 & 48 & |تمهارات التواصل الصحة الطلابية للطالبات مع & 6 \\
\hline 9 & | كبيرة & 3.43 & 0.01 & 33.70 & 6.4 & 14 & 16.5 & 36 & 28.9 & 63 & 23.9 & 52 & 24.3 & 53 & |تلوجريقة الجرشيدة في الطلابية الطالبات & 13 \\
\hline 10 & | بيرة & 3.43 & 0.01 & 30.95 & 7.3 & 16 & 16.5 & 36 & 28.4 & 62 & 21.6 & 47 & 26.1 & 57 & 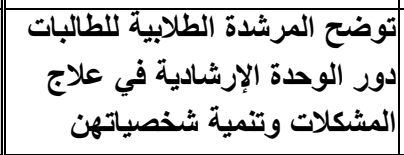 & 10 \\
\hline
\end{tabular}




\begin{tabular}{|c|c|c|c|c|c|c|c|c|c|c|c|c|c|c|c|c|}
\hline \multirow{3}{*}{ الترتيب } & \multirow{3}{*}{ - } & \multirow{3}{*}{ 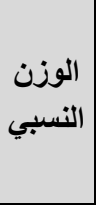 } & \multirow{3}{*}{ | الدلالة | مستوى| } & \multirow{3}{*}{ ق } & \multicolumn{10}{|c|}{ التكرارات والنسب المئوية (ن = 218) } & \multirow{3}{*}{ 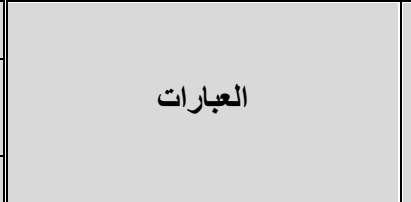 } & \multirow{3}{*}{ p } \\
\hline & & & & & \multicolumn{2}{|c|}{ لا لا أوافق بشدة | } & \multicolumn{2}{|c|}{ لا لا أوافق } & \multicolumn{2}{|c|}{ | أوافق إلى حـ } & \multicolumn{2}{|c|}{  } & \multicolumn{2}{|c|}{ أوافق بشدة } & & \\
\hline & & & & & $\%$ & $ت$ & $\%$ & $ت$ & $\%$ & $ت$ & $\%$ & 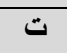 & $\%$ & $ت$ & & \\
\hline 11 & كبيرة & 3.41 & 0.01 & 23.61 & $\mid 10.1$ & 22 & 20.6 & 45 & 18.3 & 40 & 20.2 & 44 & 30.7 & 67 & 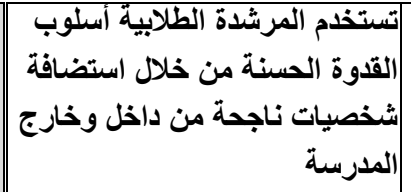 & 16 \\
\hline 12 & 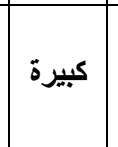 & 3.40 & 0.01 & $|19.94|$ & 13.3 & 29 & 12.4 & 27 & 22.0 & 48 & 25.7 & 56 & 26.6 & 58 &  & 2 \\
\hline 13 & |متوسطة & 3.38 & 0.01 & 32.83 & 10.1 & 22 & 14.2 & 31 & 30.7 & 67 & 17.9 & 39 & 27.1 & 59 & 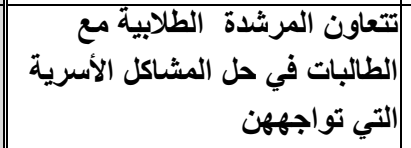 & 18 \\
\hline 14 & |متوسطة & 3.37 & 0.01 & 40.44 & 7.8 & 17 & 14.7 & 32 & 33.5 & 73 & 20.6 & 45 & 23.4 & 51 & |توعية الطالبات بالحقوة الطرابية على الطباتية & 8 \\
\hline 15 & |متوسطة & 3.34 & 0.01 & 18.19 & 10.1 & 22 & 17.4 & 38 & 25.7 & 56 & 21.6 & 47 & 25.2 & 55 & 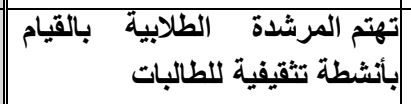 & 9 \\
\hline 16 & |متوسطة & 3.31 & 0.01 & 60.39 & 22.0 & 48 & 13.3 & 29 & 15.6 & 34 & 9.6 & 21 & 39.4 & 86 & 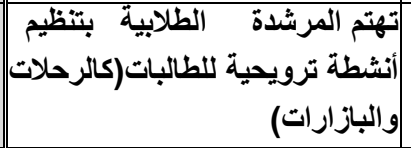 & 7 \\
\hline 17 & |متوسطة & 3.28 & 0.01 & 32.05 & 6.9 & 15 & 20.2 & 44 & 29.8 & 65 & 24.8 & 54 & 18.3 & 40 & |تدوات توعاهم المرشدة الطلابية في تنظيجات الطالبات & 12 \\
\hline 18 & | متوسطة & 3.28 & 0.01 & $|13.97|$ & 10.1 & 22 & 22.0 & 48 & 22.5 & 49 & 21.1 & 46 & 24.3 & 53 & 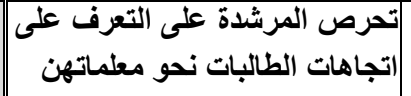 & 4 \\
\hline & 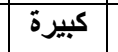 & 3.46 & & & طال! & & 0 & ج للتعل & الدافق & ذفاما & "نكان & & بيلة & & المتوسط العام للاور المر & \\
\hline
\end{tabular}

يتضح من الجدول السابق أنه نوجد فروق دالة إحصائياً بين استجابات عينة الدر اسة على عبار ات المحور الثاني (دور المرشدة الطلابية في حل مشكلة انخفاض الدافعية للتعلم )،حيث ثر اوحت قيم (كا2) لدلالة الفروق بين الاستجابات للبيانات الرتبية بين ( 13.97 - 73.10) وجميعها دالة إحصائياً عند مستوى دلالة (0.01).وبالنظر إلى الاستجابة صاحبة التكر ار الأكبر في كل عبارة من عبار ات المحور الثاني يتضح من الجدول أن الفروق كانت دالة لصالح الاستجابة (أوافق بثدة) بكل من العبار ات ذات الأرقام ( 1، 2، 4، 5، 7، 11، 15، 16، 17)، وجاءت الفروق دالة لصالح الاستجابة (أو افق) للعبارة رقم ( 6) بينما جاءت الفروق دالة لصالح الاستجابة (أو افق إلى حد ما) للعبار ات أرقام (3، 8، 9، 10، 12، 13، 14، وجاء المتوسط العام لدور المرشدة الطلابية في حل مشكلة انخفاض الدافعية للتعلم من وجهة نظر الطالبات بوزن نسبي (3.46) مما يدل على درجة موافقة (كبيرة) من وجهة نظر الطالبات على تلك الأدوار ككل. وجاءت أكثر أدوار المرشدة الطلابية في حل مشكلة انخفاض الدافعية للتعلم من وجهة نظر الطالبات اثنتي عثر دورا و التي جاء وزنها النسبي بقيمة أكبر من (3.40) مما يمثل درجة الموافقة (أوافق) من وجهة نظر الطالبات وتلاك الأدوار هي: 
ـالعبارة رقم 1 (تتعاون المرشدة الطلابية مع الطالبات لحل المشاكل التي تواجههن في المدرسة ) والتي جاءت في الترتيب الأول بوزن نسبي (3.78) ـالعبارة رقم 15 (تساهم المرشدة الطلابية في تكريم الطالبات المتفوقات ) و التي جاءت في الترتيب الثاني بوزن نسبي (3.71) ـالعبارة رقم 5 (تمنع المرشدة الطلابية وقوع العنف اللفظي على الطالبة من المعلمة ) والتي جاءت في الترتيب الثالث بوزن نسبي (3.69) بينما جاءت باقي عبار ات هذا البعد بوزن نسبي يتر اوح بين ( 3.28 - 3.28) وهو يمثل درجة

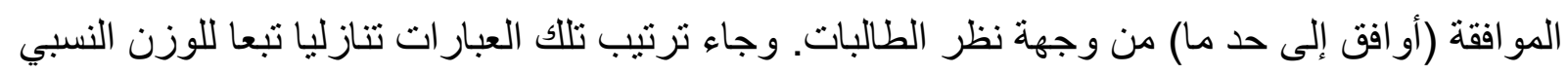
كما يلي:

ـالعبارة رقم 18 (تتعاون المرشدة الطلابية مع الطالبات في حل المشاكل الأسرية التي تواجههن ) و التي جاءت في الترتيب الثالث عشر بوزن نسبي (3.78) ـالعبارة رقم 8 (تحرص المرشدة الطلابية على توعية الطالبات بالحقوق والواجبات الطلابية ) و التي جاءت في الترنيب الرابع عشر بوزن نسبي (3.71) -العبارة رقم 9 (تهتم المرشدة الطلابية بالقيام بأنشطة تثثيفية للطالبات ) والتي جاءت في الترتيب الخامس عثر بوزن نسبي (3.69)

2011) حيث أظهرت نتائجها أن (\% $\% 3,27$
اتفقت نتائج الاراسة الحالية مع دراسة "العويس")

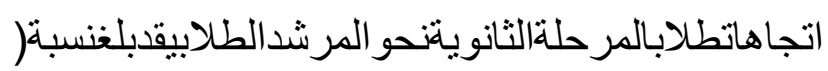


إجابة التساؤل الرابع ولإجابة على هذا السؤال، فقد نم استخدام اختبار تحليل التباين الأحادي الاتجاه

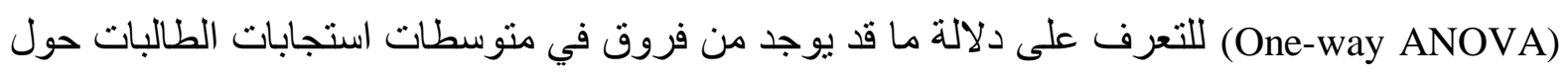
أبعاد ومحاور الدراسة،ويبين ذلك الجداول التالية:

1- الفروق بين متوسطات استجابات طالبات المرحلة الثانوية حول كل من (العو امل المدرسية المؤدية لانخفاض الدافعية للتعلم لاى طالبات المرحلة الثانوية المرتبطة بالمعلمة، والعوامل المرتبطة بالبيئة

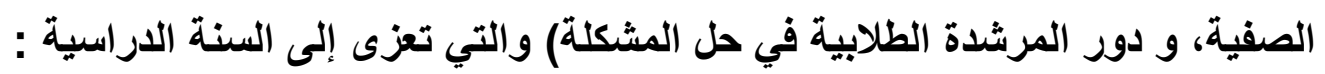

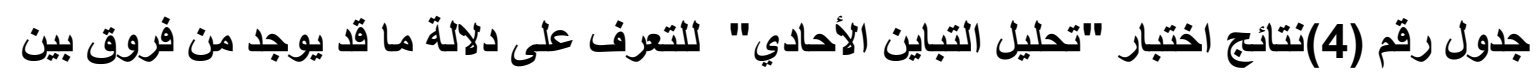
متوسطات استجابات طالبات المرحلة الثانوية حول محاور الاراسة والتي تعزى إلى السنة الدراسية لإسية

\begin{tabular}{|c|c|c|c|c|c|c|}
\hline الإحصائية & ف ت & المربعات & الحرجة & المربعات & مصادر التباين & المتغيرات \\
\hline 0.263 & 1.35 & 0.71 & $\overline{2}$ & 1.42 & بين المجموعات & البعد الأول من المحور الأول: العوامل \\
\hline
\end{tabular}




\begin{tabular}{|c|c|c|c|c|c|c|}
\hline & & 0.53 & 215 & 113.82 & داخل المجموعات & المدرسية المؤدية لانخفاض الدافعية \\
\hline & & & 217 & 115.24 & الكلي & للتعلم المرتبطة بالمعلمة \\
\hline \multirow[t]{3}{*}{0.195} & 1.65 & 1.03 & 2 & 2.06 & بين المجموعات & \multirow{3}{*}{ الانففاض الثاني: العوامل المدرسية المؤدية } \\
\hline & & 0.63 & 215 & 134.76 & داخل المجموعات & \\
\hline & & & 217 & 136.82 & الكلي & \\
\hline \multirow[t]{3}{*}{${ }^{*} 0.032$} & 3.50 & 2.32 & 2 & 4.65 & بين المجموعات & \multirow{3}{*}{ في حل مشكلة الخفاض دافئ دافعية طالبات المرشدة الطلابية } \\
\hline & & 0.66 & 215 & 142.60 & داخل المجموعات & \\
\hline & & & 217 & 147.24 & الكلي & \\
\hline
\end{tabular}

* دال إحصائياً عذ مستوى دلالة (0.05)



متوسطات استجابات طالبات المرحلة الثانوية حول كل من (العو امل المدرسية المؤدية لانخفاض الدافعية

للتعلم لدى طالبات المرحلة الثانوية المرتبطة بالمعلمة، والعو امل المرتبطة بالبيئة الصفية) تعزى إلى السنة الدر اسية، حيث جاءت قيم (ف) للمجموع الكلي لبعدي المحور الأول عند مستويات دلالة أكبر من (0.05). كما يتبين من الجدول السابق أيضا أنه توجد فروق ذات دلالة إحصائية عند مستوى الدلالة ( 0.05) بين متوسطات استجابات طالبات المرحلة الثانوية حول دور المرشدة الطلابية في حل مشكلة انخفاض دافعية طالبات المرحلة الثانوية للتعلم تعزى إلى السنة الدراسية، حيث جاءت قيمة (ف) للمحور الثاني بقيمة (3.50) و هي دالة إحصائياً عند مستوى دلالة (0.05) وللتعرف على اتجاه الفروق بالنسبة للمحور الثاني (دور المرشدة الطلابية في حل مشكلة انخفاض دافعية طالبات المرحلة الثانوية للتعلم) ، فقد نم استخدام اختبار للمقارنات البعدية ويوضح نتائجه

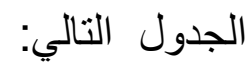
جدول رقم (5)نتائج اختبار LSD للمقارنات البعدية لمعرفة اتجاه الفروق بين متوسطات استجابات طالبات المرحلة الثانوية حول دور المرشدة الطلابية في حل مشكلة انخفاض دافعية طالبات المرحلة الثانوية للتعلم والتي تعزى إلى السنة الاراسية

\begin{tabular}{|c|c|c|c|c|c|c|}
\hline الثانوي & الثانوي & الثانوي & المستوسط & العدد & السنة الدراسية & المتغير \\
\hline${ }^{*} 0.38$ & & - & 3.65 & 62 & الأول الثانوي & \multirow{3}{*}{ في حل مشكلة انخفاض دالثاني: دور المرشدة الطلابية } \\
\hline & - & & 3.47 & 91 & الثاني الثانوي & \\
\hline - & & & 3.27 & 65 & الثالث الثانوي & \\
\hline
\end{tabular}

* دال إحصائياً عند مستوى دلالة (0.05)

يتبين من الجدول السابق أنه بالنسبة للمحور الثاني (دور المرشدة الطلابية في حل مشكلة انخفاض دافعية طالبات المرحلة الثانوية للتعلم) كان اتجاه الفروق لصالح استجابات طالبات الصف الأول الثانوي مقابل استجابات طالبات الصف الثالث الثانوي 
2- الفروق بين متوسطات استجابات طالبات المرحلة الثانوية حول كل من (العوامل المدرسية المؤدية لانخفاض الدافعية للتعلم لدى طالبات المرحلة الثانوية المرتبطة بالمعلمة، والعوامل المرتبطة بالبئية

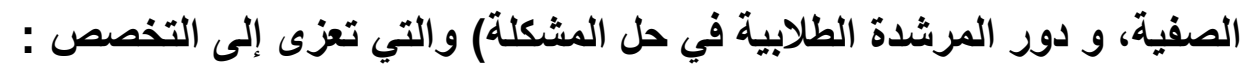

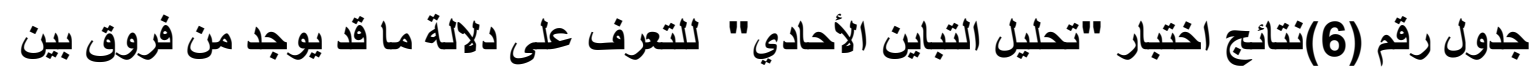

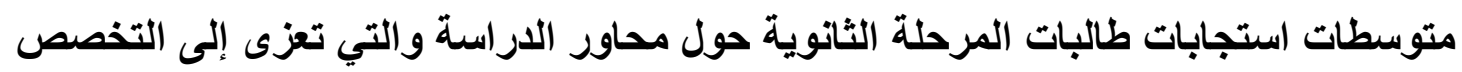

\begin{tabular}{|c|c|c|c|c|c|c|}
\hline $\begin{array}{c}\text { الإحصائية } \\
\text { الالائة }\end{array}$ & ف & المربعات & الحرية & المربعات & مصادر التباين & المتغيرات \\
\hline \multirow[t]{3}{*}{0.379} & 0.98 & 0.52 & 2 & 1.04 & بين المجموعات & \multirow{3}{*}{ البدالية الأول من المحور الأول: العوامل } \\
\hline & & 0.53 & 215 & 114.20 & داخل المجموعات & \\
\hline & & & 217 & 115.24 & الكلي & \\
\hline \multirow[t]{3}{*}{0.072} & 2.66 & 1.65 & 2 & 3.31 & بين المجموعات & \multirow{3}{*}{ البحداض الثاني: العوامل المدرسية المؤدية } \\
\hline & & 0.62 & 215 & 133.51 & داخل المجموعات & \\
\hline & & & 217 & 136.82 & الكلي & \\
\hline \multirow[t]{3}{*}{${ }^{* * *} 0.008$} & 4.94 & 3.23 & 2 & 6.47 & بين المجموعات & \multirow{3}{*}{ في حل مشكلة انخفاض دافعية الثانية دور المرشدة الطلابية } \\
\hline & & 0.65 & 215 & 140.78 & داخل المجموعات & \\
\hline & & & 217 & 147.24 & الكلي & \\
\hline
\end{tabular}

* * * دال إحصائيا عند مستوى دلالة (0.01)

يتبين من الجدول السابق عدم وجود فروق ذات دلالة إحصائية عند مستوى الدلالة ( 0.05) بين متوسطات استجابات طالبات المرحلة الثانوية حول كل من (العو امل الدرسية المؤدية لانخفاض الدافعية للتعلم لدى طالبات المرحلة الثانوية المرتبطة بالمعلمة، و العو امل المرتبطة بالبيئة الصفية) تعزى إلى التخصص، حيث جاءت قيم (ف) للمجموع الكلي لبعدي المحور الأول عند مستويات دلالة أكبر من (0.05). كما يتبين من الجدول السابق أيضا أنه توجد فروق ذات دلالة إحصائية عند مستوى الدلالة ( 0.01) بين متوسطات استجابات طالبات المرحلة الثانوية حول دور المرشدة الطلابية في حل مشكلة انخفاض دافعية طالبات المرحلة الثانوية للتعلم تعزى إلى التخصص، حيث جاءت قيمة (ف) للمحور الثاني بقيمة ( 4.94) و هي دالة إحصائياً عند مستوى دلالة (0.01). وللتعرف على اتجاه الفروق بالنسبة للمحور الثاني (دور المرشدة الطلابية في حل مشكلة انخفاض دافعية طالبات المرحلة الثانوية للتعلم) ، فقد نم استخدام اختبار LSD للمقارنات البعدية ويوضح نتائجه الجدول النالي: - n

جدول رقم (7)نتائج اختبار LSD للمقارنات البعدية لمعرفة اتجاه الفروق بين متوسطات استجابات طالبات المرحلة الثانوية حول دور المرشدة الطلابية في حل مشكلة انخفاض دافعية طالبات المرحلة الثانوية للتعلم والتي تعزى إلى التخصص فلنص لتصن

\begin{tabular}{|c|c|c|c|c|c|c|}
\hline أدبي & علمي & عام & المتوسط & العدد & التخصص & المتغير \\
\hline
\end{tabular}




\begin{tabular}{|c|c|c|c|c|c|c|}
\hline & & & الحسابي & & & \\
\hline & ${ }^{* *} 0.39$ & - & 3.65 & 62 & عام & \multirow{3}{*}{ الطلابية في حل مشكلة الثاني: دور المرشدة } \\
\hline & - & & 3.27 & 94 & علمي & \\
\hline- & ${ }^{* *} 0.30$ & & 3.57 & 62 & أدبي & \\
\hline
\end{tabular}

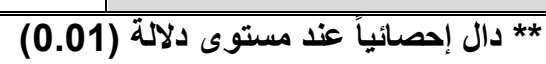

يتبين من الجدول السابق أنه بالنسبة للمحور الثاني (دور المرشدة الطلابية في حل مشكلة انخفاض دافعية طالبات المرحلة الثانوية للتعلم) كان اتجاه الفروق لصالح استجابات كل من طالبات التخصص الأدبي و التخصص العام مقابل استجابات طالبات التخصص العلمي.بمعنى أن طالبات التخصص الأدبي و التخصص العام أكثر مو افقة على قيام المرشدة الطلابية بدور ها في حل مشكلة انخفاض الدافعية للتعلم، أكثر من طالبات التخصص العلمي.

3- الفروق بين متوسطات استجابات طالبات المرحلة الثانوية حول كل من (العوامل المدرسية المؤدية لانخفاض الدافعية للتعلم لاى طالبات المرحلة الثانوية المرتبطة بالمعلمة، والعوامل المرتبطة بالبيئة الصفية، و دور المرشدة الطلابية في حل المشكلة) والتي تعزى إلى الحالة التعليمية للأب : جدول رقم (8)نتائج اختبار "تحليل التباين الأحادي" للتعرف على دلالة ما قد يوجد من فروق بين متوسطات استجابات طالبات المرحلة الثاتوية حول محاور الدراسة والتي تعزى إلى الحالة التعليمية للأب

\begin{tabular}{|c|c|c|c|c|c|c|}
\hline الإحصائية & ف ف & المربعات & الحرية & المربعات & مصادر التباين & المتغيرات \\
\hline \multirow[t]{3}{*}{0.942} & 0.06 & 0.03 & 2 & 0.06 & بين المجموعات & \multirow{3}{*}{ البدال اللعدية المؤدية لانففاض المحور الأول: العوامل } \\
\hline & & 0.54 & 215 & 115.18 & داخل المجموعات & \\
\hline & & & 217 & 115.24 & الكلي & \\
\hline \multirow[t]{3}{*}{0.055} & 2.93 & 1.82 & 2 & 3.64 & بين المجموعات & \multirow{3}{*}{ البعد الثاني: العوامل المدرسية المؤدية } \\
\hline & & 0.62 & 215 & 133.18 & داخل المجموعات & \\
\hline & & & 217 & 136.82 & الكلي & \\
\hline \multirow[t]{3}{*}{0.964} & 0.04 & 0.02 & $\overline{22}$ & 0.05 & بين المجموعات & \multirow{3}{*}{ في حل مشكلة انخفاض دافي: دور المرشدة الطلابية. } \\
\hline & & 0.68 & 215 & 147.19 & داخل المجموعات & \\
\hline & & & 217 & 147.24 & الكلي & \\
\hline
\end{tabular}

يتبين من الجدول السابق عدم وجود فروق ذات دلالة إحصائية عند مستوى الدلالة ( 0.05) بين متوسطات استجابات طالبات المرحلة الثانوية حول كل من (العو امل المدرسية المؤدية لانخفاض الدافعية للتعلم لدى طالبات المرحلة الثانوية المرتبطة بالمعلمة، والعو امل المرتبطة بالبيئة الصفية و دور المرشدة الطلابية في حل مشكلة انخفاض دافعية طالبات المرحلة الثانوية للتعلم) تعزى إلى الحالة التعليمية للأب ، حيث جاءت قيم (ف) للمجموع الكلي لبعدي المحور الأول وللمحور الثاني عند مستويات دلالة أكبر من (0.05). 
وقد يرجع ذلك إلى وعي الطالبات الذاتي و إدر اكهن لسمات البيئة التعليمية الدحفزة للتعلم من عدمها،كمايعكس و عيهن بالأدوار التي تقوم بها المرشدة الطلابية في المدرسة. 4- الفروق بين متوسطات استجابات طالبات المرحلة الثانوية حول كل من (العوامل العدرسية|لمؤدية

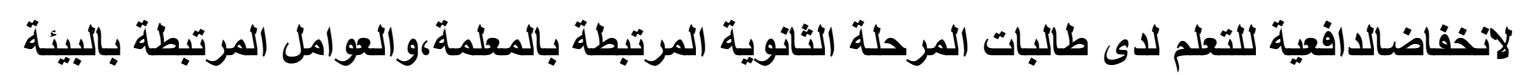



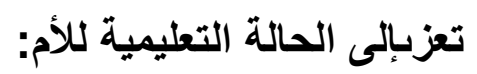

جدول رقم (9)نتائج اختبار "تحليل التباين الأحادي" للتعرف على دلالة ما قد يوجد من فروق بين

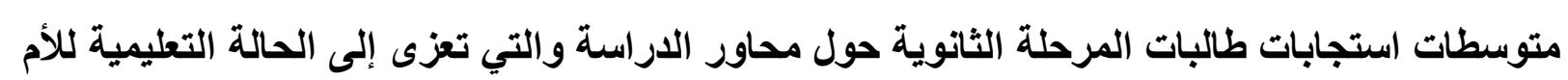

\begin{tabular}{|c|c|c|c|c|c|c|}
\hline الإحصائية & ف & مالمربعات & الحرية & المربعات & مصادر التباين & المتغيرات \\
\hline \multirow[t]{3}{*}{0.685} & 0.38 & 0.20 & 2 & $\overline{0.40}$ & بين المجموعات & \multirow{3}{*}{ 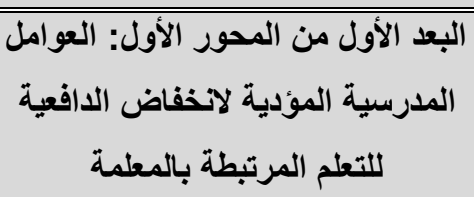 } \\
\hline & & 0.53 & 215 & 114.84 & داخل المجموعات & \\
\hline & & & 217 & 115.24 & الكلي - ل الكي & \\
\hline \multirow[t]{3}{*}{0.882} & 0.13 & 0.08 & 2 & 0.16 & بين المجموعات & \multirow{3}{*}{ لالبذاض الثاني: العوامل الددرسية المؤدية } \\
\hline & & 0.64 & 215 & 136.66 & داخل المجموعات & \\
\hline & & & 217 & 136.82 & الكلي & \\
\hline \multirow[t]{3}{*}{0.229} & $\overline{1.49}$ & 1.00 & 2 & 2.01 & بين المجموعات & \multirow{3}{*}{ في حل مشكلة الثاني: دور المرشدة الطلابية } \\
\hline & & 0.68 & 215 & 145.24 & داخل المجموعات & \\
\hline & & & 217 & 147.24 & الكلي & \\
\hline
\end{tabular}

تبين من الجدول السابق عدم وجود فروق ذات دلالة إحصائية عند مستوى الدلالة ( 0.05) بين متوسطات



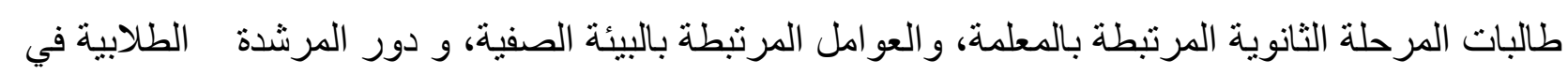

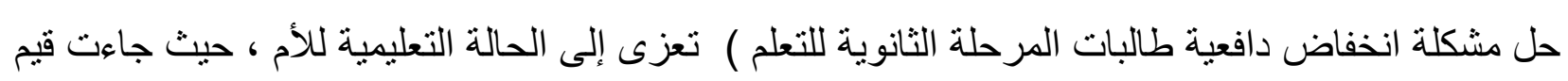
(ف) للمجموع الكلي لبعدي المحور الأول وللمحور الثاني عند مستويات دلالة أكبر من (0.05). 


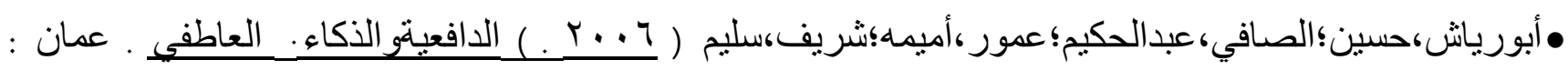
دار الفكر. العو املالمؤثرة علنتنميةالدافعيةلدالطلبةفيالمدارسالأساسيةفى

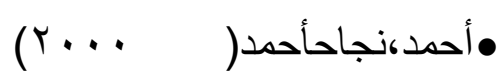
منطقةعمانالكبرى،رسالةماجستير غير منشورة، الجامعةالأردنية، عمان، الأردن. •الإدارة العامة للتخطيط و السياسات،وكالة وزارة للتخطيط ( 2014،2010) ـالخطة التشغيلية "خطة التتمية التاسعة"، الرياض :وزارة التربية و التعليم،تعليم البنات.

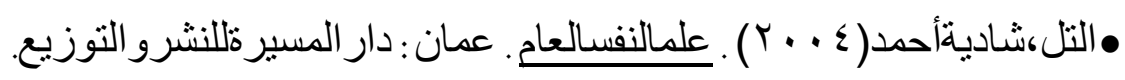

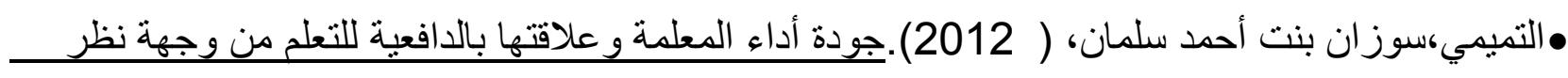

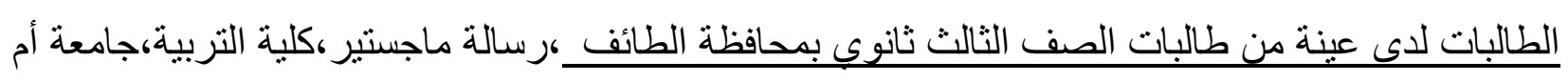
القرى،مكة المكرمة.

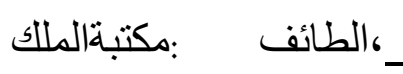
الاليلالعمليفيالإرشادالطلاببي 2003م • (الثهري،سالمسعيد فهدالوطنية. ، الكويت، 1988) الأهدافالتربويةتصنيفهاو تحديدهالسلوكي

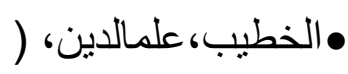
مكتبة الفلاح. •الخطيب،محمد(2007) الجودةفيالتعليمالعام،ور قة عملمقدمةللقاء السنو يالر ابععشر ، الجمعيةالسعو ديةللعلو مالتربو يةو النفسية (جستن) ،15-16 مايو ،السعودية. •الر افعي،يحيى بن عبداله.( 2009م) أثز طريقة التنديس المستخدمة في تتمية دافعية التعلم والتحصيل


كلية التربية،جامعة عين شمس. 
•الزبيدي،كامل،العكايشي،بشرى،( 2005م). أسباب انخفاض التحصيل الدر اسي لدى طلبة الجامعة في العر اق،رسالة ماجستير ،كلية التربية و الآداب،جامعة العراق. •الزرنوجي،بر هانالدين(1985)تعليمالمتعلمفيطريقالتعلم،تحقيقصلاحمحدالخيمي_ ونذير حمدان،دمشق،دار ابن كثير . فاعليةتدريسالعلو مو فقالتدريسالمدمجالقائمعلنظريتي

الذكاءاتالمتعددةو أساليبالتعلمفيتنميةالاستيعابالمفاهيميو الدافعيةللتعلم ـــالمجلة|الدوليةللأبحاث التربوية،جامعة الإمار ات العربية.

$$
\text { عائض بن }
$$

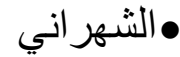

سعد(2009)، الخدمةالاجتماعيةثموليةالتطبيقو مهنة|الممارسة،ط2،جدة:خو ارزمالعلميةللنشرو التوزيع.

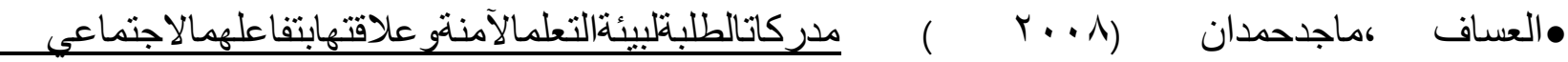
و دافعيتهمللتعلم،رسالةدكتور اه،كليةالدر اساتالتربوية|العليا،جامعة عمانالعربية،الأردن. •العناني،حنانعبدالحميد(0 ؟) .علمالنفسالتربوي، ط (ب)، عمان : دارصفاءللنشرو التوزيع •العنزي،خالد بن الحميدي(2004م) دور المرشد الطلابي كما بدركه مديرو المدارس المتوسطة والثانوية في الإدارة العامة للتعليم بمنطقة الحدودالثمالية،رسالة ماجستير ،كلية التربية،جامعة الملك سعود،الرياض. •العويس،سليمان عبدالله(2011م) اتجاهات طلاب المرحلة الثانوية نحو المرشد الطلابي بمدينة بريده، رسالة ماجستير ،كلية العلوم الإجتماعية قسم علم النفس،جامعة الإمام محمد بن سعود،الرياض. •الغامدي،مساعد سعيد(1413ه)،الخصائص الإرشادية والإستعداد الإجتماعي لدى المرشدين المؤهلين و غير المؤهلين في المرحلة الثانوية(رسالة ماجستير غير منشورة)،كلية التربية ،جامعة أم القرى ،مكة المكرمة. •المقرحي،سعاد أبو بكر(2005م)،بعض العو امل الاجتماعيةو التعليمية و أثر ها في التحصيل الدراسي "در اسة ميدانية على مدينة طر ابلس"،رسالة ماجستير، كلية الآداب، قسم الخدمة الاجتماعية، جامعة الفاتح،طر ابلس. تقييمالبيئة|لصفيةو تطوير هاقيدروسالعلو مللصفالخامس

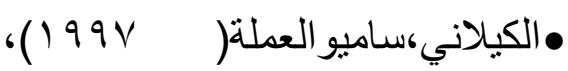
مجلةالجامعةا لإسلامية،مجلده ، MCI " الأساسيفيثلاثمدارسفلسطينيةاستخدامترجمة عربيةلمقياس، عدد • •الكيلاني،ماجدعرسان(1988) أهدافالتربيةالإسلامية،ط2، المدينة|لمنورة،دار التراث. •المعايطة، عبدالعزيز ،و الجغيمان،محمد (2009) مشكلاتثربويةمعاصرة. عمان : دار التقافتللنشرو التوزيع. •المرسي، السيد محمد ،(2007م)، التحليل البيئي( swot) الرباعي،كليةالعلوم،جامعة المنصورة.

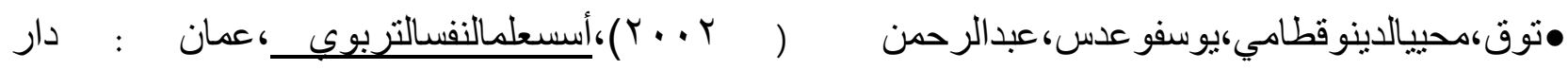
الفكر للطباعةو النشرو التوزيع. 


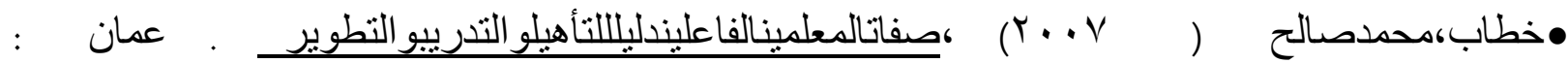
دار المسيرةّللنشرو التوزيع.

•خليفة،محمد عبداللطيف،(2001م)،الدافعية والتعلم،ط1،دار غريب للطباعة و النشر، ،القاهرة. •رشوان،حسين عبدالحميد أحمد،(1998)،علع اجتماع المر أة،المكتب الجامعي الحديث،الإسكندرية •رضوان،وسام سعيد( 2004م)،الدافع المعرفي و البيئة الصفية وعلاقتهما بالتفكير الإبتكاري لدى طلاب

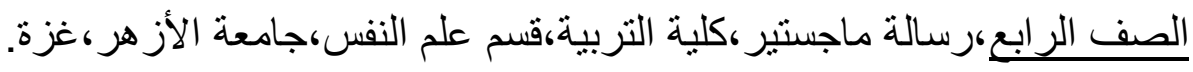

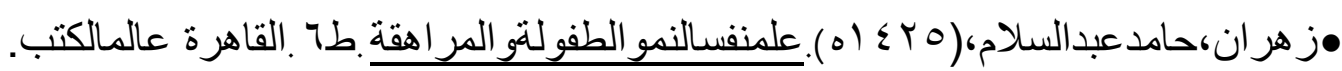
•سمارة، عزيزونمر ،عصام ( ب9919م)محاضر اتفيالتو جيهو الإرشاد، عمان:دار الفلكو.



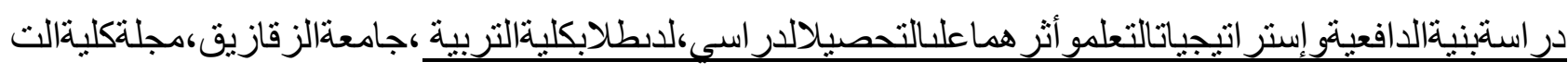
ربية،جامعةالزقازيق.

•عودة،محمد عبد الرحيم( 2009م) أسباب الرسوب الدراسي، ــرسالة ماجستير غير منشورة،كلية التربية،جامعة الملك عبد العزيز،جدة.

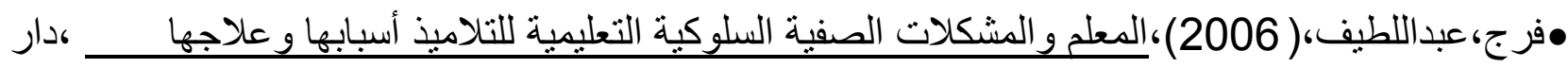

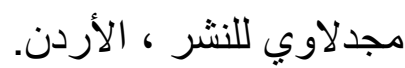
•قطامي،نايفة(1992م)أساسيات علع النفس التربوي. عمان.الأردن. r...r

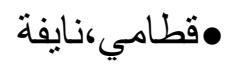

،أثرمتغير الجنس، الصف،درجةداخلية/الضبطفيدرجة|الدافعيةللتعلمعندالمتفوقيندر اسيًافيمنطقة/أغو ار الوسطى،مجل ةالعلومالتربوية،قطر. •قطامي،يو سفوقطامي،نايفة ( r . . r ) ، إدارة الصفوف، عمان : دار الفكر للطباعةو النشر و التوزيع •مجمع اللغة العربية ، (1980م) ، المعجم الوجيز ، الطبعة الأولى ، مطابع شركة الإعلانات الثرقية ، دار


2002)، مشكلاتالتعليمالعاممظاهر سلبيةو تطلعاتايجابية

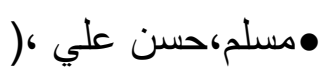
در اسةغير منشورةثقسمعلمالنفس،كلية/لتربية،جامعة|الملكسعود، الرياض. •وزارة التربية و التعليم) 2002)دليلالمرشدالطلابيلمدارسالتعليمالعام ط2،الرياض:الإدارة العامة للتوجيه و و الإرشاد. 


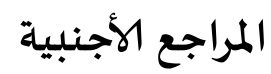

Toles، A. (2010). Effects of Teaching Strategies on Student Motivation to Learn in High School Mathematics Classes. Phd Dissertation Abstract، Walden University،ProQuest LLC،349.

Monty، J. (2003). "School-Wide discipline in urban high schools: Perceptions of violence prevention strategies". Dissertation Abstracts International، 62-11A، AA13033978، p. 3652.

Mayers، S.\& Rocca‘ K. (2001). Perceived instructor argumentativeness and verbal aggressiveness in the college classroom: Effects on student perceptions of climate، apprehension and state motivation. Western Journal of Communication‘ vol. 65، no.2‘pp.

Beckerman ، T. ‘\& Good ، T . (1981) ، " The classroom Ratio of high - and low aptitude students and its effect on achievement ". American Educationl Research Journal ، 18 ، 317 .

Skinner‘E.A\&Belmont‘M.J.(1993).Motivation in the classroom:Reciprocal effects of teacher bhhavior and student engagement across the school year.Journal of Educational Psychology‘vol.58‘no.4‘pp.571-581.

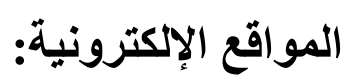

وز ارةالتربيةو التعليم(WWW.moe.gov.sa)

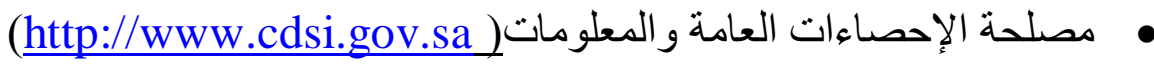


